\title{
Sedimentological and sequence stratigraphic analysis of Carboniferous deposits in western Libya: Recording the sedimentary response of the northern Gondwana margin to climate and sea-level changes
}

\author{
Sebastian Fröhlich ${ }^{\mathrm{a}, *}$, Laurent Petitpierre ${ }^{\mathrm{a}}$, Jonathan Redfern ${ }^{\mathrm{a}}$, Paul Grech ${ }^{\mathrm{b}, 1}$, \\ Stéphane Bodin ${ }^{\mathrm{a}}$, Simon Lang ${ }^{\mathrm{c}}$ \\ ${ }^{a}$ North Africa Research Group, School of Earth, Atmospheric and Environmental Sciences, The University of Manchester, Oxford Road, Manchester M13 9PL, UK \\ ${ }^{\mathrm{b}}$ Woodside Energy (N.A.) Ltd., Corinthia Bab Africa Hotel, Commercial Centre Zone C Level 3, Tripoli 91964, Libya \\ ${ }^{\mathrm{c}}$ Woodside Energy Ltd., GPO Box D188, Perth, Western Australia 6000, Australia
}

\section{A R T I C L E I N F O}

Article history:

Received 22 February 2009

Received in revised form 16 September

2009

Accepted 17 September 2009

Available online $\mathrm{xxxx}$

\section{Keywords:}

Carboniferous

Sequence stratigraphy

Libya

Murzuq Basin

Ghadames Basin

\section{A B S T R A C T}

Detailed sedimentological and sequence stratigraphic analysis of Carboniferous (Tournaisian to Moscovian) strata exposed in the north-western Murzuq Basin and southern Ghadames Basin, western Libya, provides new insights into the sedimentary response of the northern Gondwana margin to climate and sea-level change.

The Lower Carboniferous Marar and Assedjefar Formations can be divided into five depositional sequences of 3rd order. In total 27 facies types are defined, grouped into four facies associations: offshore shales, shallow marine clastics, fluvial sandstones and marine carbonates.

The bulk of the Lower Carboniferous interval is dominated by an alternation of offshore shales and shallow marine clastics, which were deposited during the transgressive and highstand systems tracts. The clastic deposits mostly consist of laterally persistent coarsening and thickening upward cycles with a common succession from basal hummocky cross-stratified sandstones to ripple-laminated sandstones, capped by multidirectional cross-stratified sandstones.

Within the lowstand systems tracts, lenticular sandbodies have been identified, which vary in thickness from $1.5 \mathrm{~m}$ (ca. $40 \mathrm{~m}$ wide) to $50 \mathrm{~m}$ (ca. $1.5 \mathrm{~km}$ wide). These are interpreted to be fluvial channel complexes based on their geometry, erosive base, and presence of thick stacked sandstones with unidirectional planar and trough cross-bedding, the absence of bioturbation and occurrence of land plant fragments. These channel complexes mostly cut down into offshore shales, and are interpreted to be bound at the base by sequence boundaries. Palaeogeographic maps generated for each lowstand system show the location and palaeoflow direction of these fluvial channel complexes. They are interpreted to represent large incised valleys filled with thick fluvial sandstones. Their identification and distribution indicates repeated exposure of large areas of western Libya, most-likely controlled by major eustatic sea-level changes.

The Assedjefar Formation exibits a gradual decrease in coarse clastic sediment supply throughout the Serpukhovian and by the Bashkirian and Moscovian during the deposition of the Dembaba Formation a carbonate depositional system was established. Limestones are dominantly made up of a heterozoan fauna (brachiopods, crinoids, bryozoans, gastropods) and are mostly preserved as shallow marine storm and coastal deposits. It is hypothesised that a local increase in aridity and/or the gradual erosion and decreasing topography of the hinterland mountains, with the resulting reduction in discharge, controlled this shift from clastic to carbonate deposition.

Available data indicate that the Murzuq Basin was interconnected with the Ghadames Basin at this time and is a postdepositional basin with respect to the Carboniferous interval. The sedimentological and sequence stratigraphic data from the present study offer new insights into the depositional setting and facies distribution in the Carboniferous, and the recognition of major incised fluvial systems has significant implications in the search for potential Carboniferous hydrocarbon reservoirs in the Murzuq, Ghadames, and Illizi Basins.

(c) 2009 Elsevier Ltd. All rights reserved.

\footnotetext{
* Corresponding author. Present address: Statoil ASA, Mølnholtet 42, 9481 Harstad, Norway. Tel.: +47 90693258 ; fax: +47 77045644.

E-mail address: sebo.froe@gmx.de (S. Fröhlich).

1 Present address: PETROM S.A., 1 Piata Eroilor, 100316 Ploiesti, Prahova, Romania.
}

1464-343X/\$ - see front matter (c) 2009 Elsevier Ltd. All rights reserved.

doi:10.1016/j.jafrearsci.2009.09.007 


\section{Introduction}

Two large sedimentary basins dominate the geology of western Libya: the Murzuq Basin in the south and the Ghadames Basin in the north. Both basins are major petroleum provinces in North Africa, although to-date the Carboniferous has not been a major reservoir target, with only limited hydrocarbons encountered in the Ghadames Basin. Thick Carboniferous deposits occur in the subsurface throughout the Murzuq and Ghadames Basins (Belhaj, 2000; Abugares, 2003), with extensive outcrops around the Murzuq Basin and in the southern Ghadames Basin. The outcrops are mostly in remote desert regions, and only limited previous work has been undertaken on their sedimentology and depositional environment.

In this paper we present results from two extensive field campaigns in 2007 and 2008 to locations in western Libya. The studied outcrops provide representative sections through the Carboniferous for both the northern Murzuq and southern Ghadames region.

This paper (1) presents the depositional and palaeogeographic evolution of the Marar Fm., Assedjefar Fm., and Dembaba Fm., which provide an example of a transition from a siliciclastic to a carbonate system, recording the last stage of marine deposition on northern Gondwana before the Hercynian Orogeny; (2) establishes a regional sequence stratigraphic framework to facilitate the interpretation of Carboniferous subsurface data in the Murzuq, Ghadames and Illizi Basins, and (3) assesses the influence of climate and glacio-eustasy on observed relative sea-level and facies changes from Tournaisian to Moscovian times.

\section{Geological background and previous work}

Following formation of Gondwana at the end of the Pan-African Orogeny $580 \mathrm{Ma}$ ago, throughout the Palaeozoic western Libya was located between a large exposed continental landmass in the south and the Palaeotethys in the north (Guiraud et al., 2005). Siliciclastic-dominated deposits, more than $1 \mathrm{~km}$ thick, accumulated from Cambrian to Late Devonian times. The dominant depositional envi- ronments were shallow marine and hemipelagic (with deposition of dark graptolitic shales at certain stratigraphic horizons), fluvial and periglacial (during the Ordovician) (Grubic et al., 1991).

The Carboniferous interval of the Murzuq Basin margins was first described by Klitzsch $(1963,1970)$ after earlier mentions e.g. by Krumbeck (1906) and Lelubre (1948). An interpretation of the sedimentology of the Tournaisian and Viséan Marar Formation in the southern Ghadames Basin was subsequently undertaken by Whitbread and Kelling (1982). They interpreted the succession as a fluvial/marine deltaic system. Grubic et al. (1991) provided an overview of the Phanerozoic stratigraphy of SW Libya, in which they interpreted the Tournaisian to Moscovian Marar, Assedjefar and Dembaba Formations as being entirely marine clastic and carbonate deposits. Several studies provided biostratigraphic data both from outcrop and subsurface samples (e.g. Vachard and Massa, 1984; Mergl and Massa, 2000).

During the Early Carboniferous, western Libya was most-likely situated at a palaeolatitudinal position between $40^{\circ}$ and $30^{\circ}$ south, with the gradual northward drift of Gondwana shifting the position to between $30^{\circ}$ and $20^{\circ}$ south by the Late Carboniferous (McKerrow et al., 2000; Scotese, 2000; Tait et al., 2000).

Two large intra-cratonic sag-basins dominate western Libya: the Murzuq Basin in the south and the Ghadames Basin in the north (Fig. 1). The former is bounded to the west by the Tihemboka High and to the north by the Gargaf/Atshan Uplift, which separates the Murzuq from the Ghadames Basin. Both uplifts were active throughout the Phanerozoic, e.g. during the Middle and Late Devonian and the Late Carboniferous (e.g. Grubic et al., 1991; Davidson et al., 2000; Hallett, 2002). The Murzuq Basin is bounded by the Tibesti High to the east and extends into Niger to the south, where it is called Djado Basin (Bellini and Massa, 1980). A complete Carboniferous succession (i.e. Marar, Assedjefar, Dembaba, and Tiguentourine Formation) occurs throughout most of the Murzuq Basin (Hallett, 2002), although a mid-Carboniferous compression created localised erosional unconformities between the Marar Fm. and the Assedjefar Fm. in some locations in the centre of the basin (Davidson et al., 2000).

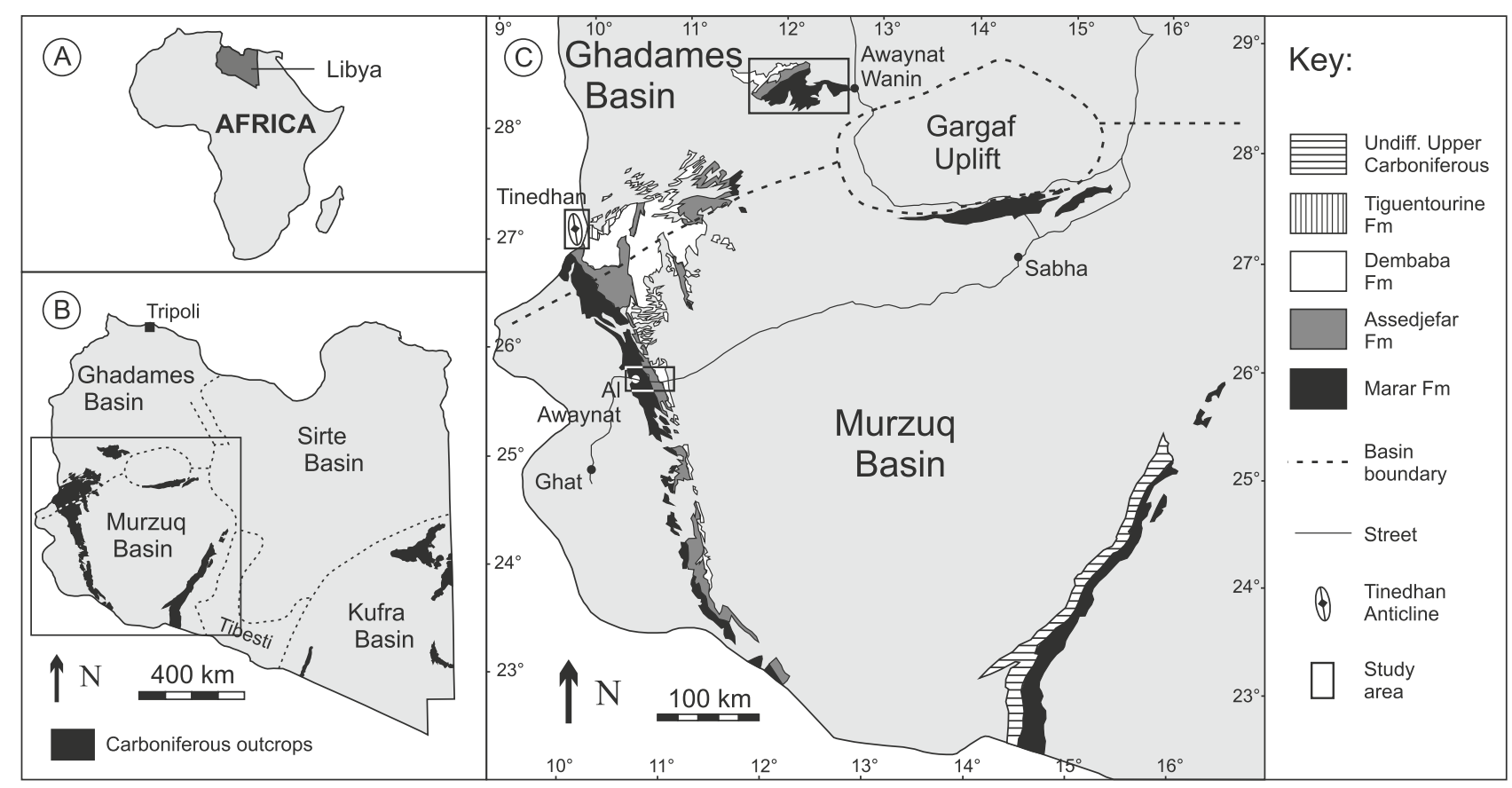

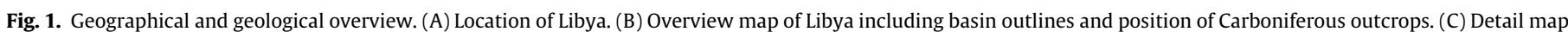

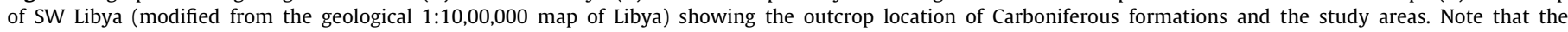
Tiguentourine Fm. only crops out in a small area east of Tinedhan. 
The Ghadames Basin is bounded to the north by the Dahar-Naffusah High; its eastern flank is concealed by the overlapping of the younger Sirt Basin. To the west, the Ghadames Basin extends into southern Tunisia and Algeria, where it is also called the Illizi and Berkine Basin. Due to considerable uplift and erosion during the Hercynian Orogeny, Carboniferous deposits are only preserved in the southern half of the Ghadames Basin, unconformably overlain by Mesozoic strata (Echikh, 1998).

In this study three field locations were investigated which offer excellent exposures of the Marar, Assedjefar and Dembaba Formations (Fig. 1): (1) Close to the town of Al Awaynat (GPS N25 $46^{\prime} 51^{\prime \prime}$ E10 $33^{\prime} 40^{\prime \prime}$ ), the Carboniferous strata are virtually unaffected by tectonics and can easily be accessed from a road. This outcrop is part of the western Murzuq Basin. (2) About $170 \mathrm{~km}$ NNW of Al Awaynat, the Tinedhan Anticline (GPS N27 $10^{\prime} 51^{\prime \prime}$ E9 ${ }^{\circ} 56^{\prime} 46^{\prime \prime}$ ) is located in westernmost Libya, close to the Algerian border. This spectacular outcrop does not currently appear on the geological maps of Libya. It represents the southernmost part of the Ghadames Basin. (3) About $270 \mathrm{~km}$ NE of Tinedhan, a Carboniferous succession dipping with a low angle NW can be studied below a wide escarpment of Cretaceous rocks west of Awaynat Wanin (GPS N28 $29^{\prime} 33^{\prime \prime}$ E12 ${ }^{\circ} 41^{\prime} 15^{\prime \prime}$ ). This is the northernmost outcrop of Carboniferous deposits in Libya; it is situated in the southern Ghadames Basin.

In the following section, a brief summary is presented of the Carboniferous formations of western Libya based on published data.

\subsection{Marar Formation}

The age of the Marar Formation is late Tournaisian to latest Viséan (Massa et al., 1974; Grubic et al., 1991; Mergl and Massa, 2000). The onset of Carboniferous deposition in western Libya is marked by a major transgression during the late Tournaisian (e.g. Massa et al., 1974; Mergl and Massa, 2000). Due to large-scale pre-Carboniferous erosion along the north-western flank of the Murzuq Basin, which is related to the uplift of the Tihemboka Arch, the base of the Marar Formation unconformably overlies Devonian and Silurian rocks (Jakovljevic, 1984; Protic, 1984; Grubic et al., 1991). The term "Marar Formation" was first introduced by Lelubre (1948). Its thickness ranges from $45 \mathrm{~m}$ in south-western Libya (Galecic, 1984), increasing northward to almost $800 \mathrm{~m}$ in the central Ghadames Basin (Mergl and Massa, 2000). According to Grubic et al. (1991), in the western Murzuq Basin the Marar Formation is dominated by thickening and coarsening upward cycles, made up of shales, siltstones and sandstones with ripple-marks and crossbedding. A shallow marine environment was proposed by these authors. Well data from the north-western Murzuq Basin (Aziz, 2000) and outcrop data from the southern Ghadames Basin (Whitbread and Kelling, 1982) were interpreted to record a deltaic and shallow marine depositional environment.

\subsection{Collenia unit}

The top of the Marar Formation is characterised by algal stromatolites, the Collenia Beds. This regional marker bed is easy to recognise in the field and occurs throughout western Libya (with the exception of the southernmost Murzuq Basin), in the Illizi Basin in Algeria and the Djado Basin in Niger (e.g. Freulon, 1953; Protic, 1984; Mergl and Massa, 2000). Several authors have dated the Collenia unit using different groups of micro- and macro-fauna (Massa et al., 1974, 1980; Vachard and Massa, 1984; Grubic et al., 1991; Coquel and Massa, 1993), and the most recent work confirms an upper Viséan age in the Illizi, Ghadames, Murzuq and Djado Basins based on brachiopods, foraminifera and conodonts (Mergl and Massa, 2000). This unit is a good regional marker for fieldwork and can be recognised in subsurface well data using typical wireline logging suites.

\subsection{Assedjefar Formation}

The age of this formation, which was first identified by Lelubre (1952), was determined as Viséan-Namurian mostly from macrofauna outcrop samples in the south-western Murzuq Basin (Galecic, 1984) and the southern Ghadames Basin (Berendeyev, 1985). However, a subsequent review of available subsurface and outcrop data from western Libya showed that the Assedjefar Formation is most-likely restricted to the Serpukhovian stage, mainly based on foraminifera and conodonts (Mergl and Massa, 2000) (Fig. 2). There is no major change in depositional environment from the underlying Marar Formation, and the Assedjefar Formation comprises a cyclic repetition of shales and sandstones, with intercalated bioclastic limestone layers towards the top. A marine depositional environment was proposed by Grubic et al. (1991) and Jakovljevic (1984). Aziz (2000) suggested a non-marine environment for siltstones and a shoreface environment for sandstones of the Assedjefar Formation based on subsurface data from the north-western Murzuq Basin.

\subsection{Dembaba Formation}

This formation was first introduced by Lelubre (1952), and it represents the last marine deposits before the onset of the Hercynian Orogeny. Berendeyev (1985) proposed a Bashkirian to Gzhelian age based on macro-fossil occurrences in the Hamadat Tanghirt area in the southern Ghadames Basin, however, there is a common agreement among most authors based on micro- and macro-fossil assemblage studies from different areas throughout western Libya that the age of this formation is restricted to the Bashkirian and Moscovian stages (e.g. Galecic, 1984; Jakovljevic, 1984; Vachard and Massa, 1984; Mergl and Massa, 2000). The lithology is dominated by fossiliferous limestones interbedded with shales. A shallow marine to intertidal environment is proposed by Grubic et al. (1991) for the western Murzuq Basin. Subsurface data suggest a gradual change from open-marine shallow shelf conditions in the northern Murzuq Basin to a more restricted lagoonal environment towards the south (Hallett, 2002). A conspicuous beige-yellow sandstone marker horizon within the Dembaba Formation, which contains ooids made of analcite, reaches a thickness of close to $30 \mathrm{~m}$ around $\mathrm{Al}$ Awaynat ('Analcim-

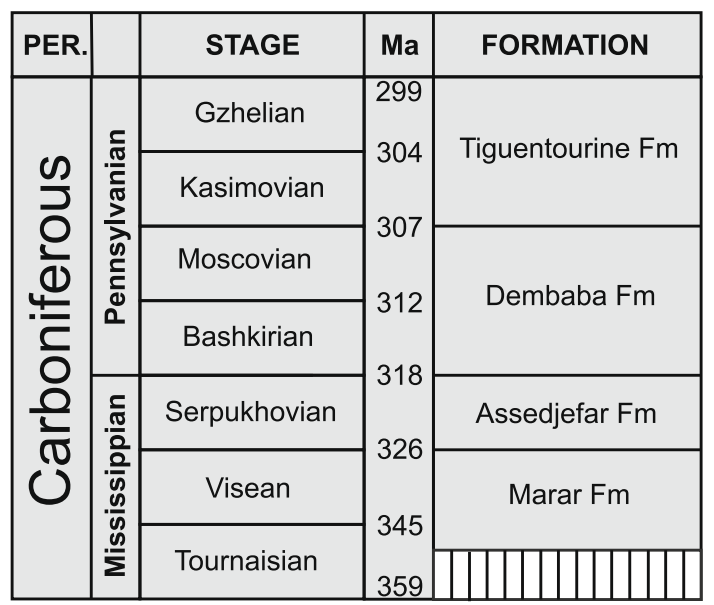

Fig. 2. Carboniferous stratigraphy (Menning et al., 2006) and age of formations in Libya. 
Table 1

Sedimentary facies.

\begin{tabular}{|c|c|c|c|c|c|}
\hline Facies & Textures & Structures & Biota and bioturbation & $\begin{array}{l}\text { Stratigraphic } \\
\text { occurrence }\end{array}$ & Interpretation \\
\hline 1: Green-beige shales & Shales & Laminated or structureless & Weak bioturbation & $\begin{array}{l}\text { Marar Fm. to } \\
\text { Dembaba } \\
\text { Fm. }\end{array}$ & $\begin{array}{l}\text { Offshore } \\
\text { marine }\end{array}$ \\
\hline 2: Brown-black shales & Shales & Laminated or structureless & Absent & $\begin{array}{l}\text { Marar Fm. to } \\
\text { Dembaba } \\
\text { Fm. }\end{array}$ & $\begin{array}{l}\text { Offshore } \\
\text { marine, low } \\
\text { oxygen } \\
\text { environment }\end{array}$ \\
\hline $\begin{array}{l}\text { 3: Horizontally } \\
\text { laminated siltstone }\end{array}$ & $\begin{array}{l}\text { Siltstone, rarely very- } \\
\text { fine-grained sandstone }\end{array}$ & $\begin{array}{l}\text { Very-thinly to thinly bedded layers. } \\
\text { Abundant horizontal lamination, rare cross- } \\
\text { lamination and grading }\end{array}$ & $\begin{array}{l}\text { Rarely small shell fragments; } \\
\text { weak bioturbation }\end{array}$ & $\begin{array}{l}\text { Marar Fm. to } \\
\text { Dembaba } \\
\text { Fm. }\end{array}$ & $\begin{array}{l}\text { Offshore } \\
\text { marine, distal } \\
\text { storm beds }\end{array}$ \\
\hline $\begin{array}{l}\text { 4: Hummocky cross- } \\
\text { stratified sandstone }\end{array}$ & $\begin{array}{l}\text { Very-fine- to fine- } \\
\text { grained sandstone, well } \\
\text { sorted }\end{array}$ & $\begin{array}{l}\text { Thinly- to thickly-bedded, medium-bedded } \\
\text { layers dominant. Abundant hummocky } \\
\text { cross-stratification, some swaley cross- } \\
\text { stratification, horizontal lamination, } \\
\text { convolute bedding, ripple lamination, in- } \\
\text { phase climbing ripples, rarely water- } \\
\text { escape-structures }\end{array}$ & $\begin{array}{l}\text { Shell debris, brachiopods, } \\
\text { moderate to high pervasive } \\
\text { bioturbation }\end{array}$ & $\begin{array}{l}\text { Marar Fm. to } \\
\text { Assedjefar } \\
\text { Fm. }\end{array}$ & $\begin{array}{l}\text { Marine, } \\
\text { between fair } \\
\text { weather and } \\
\text { storm wave } \\
\text { base }\end{array}$ \\
\hline $\begin{array}{l}\text { 5: Ripple-laminated } \\
\text { sandstone }\end{array}$ & $\begin{array}{l}\text { Very-fine- to fine- } \\
\text { grained sandstone, well } \\
\text { sorted }\end{array}$ & $\begin{array}{l}\text { Very-thinly-to medium-bedded layers, } \\
\text { interbedded with shales. Symmetrical } \\
\text { ripples, often bifurcated; rarely climbing } \\
\text { ripples }\end{array}$ & $\begin{array}{l}\text { High surface bioturbation } \\
\text { (grazing traces common) }\end{array}$ & $\begin{array}{l}\text { Marar Fm. } \\
\text { very } \\
\text { common, } \\
\text { also } \\
\text { Assedjefar } \\
\text { Fm. }\end{array}$ & $\begin{array}{l}\text { Shallow } \\
\text { marine, lower } \\
\text { shoreface } \\
\text { environment }\end{array}$ \\
\hline $\begin{array}{l}\text { 6: Multidirectional } \\
\text { cross-stratified } \\
\text { sandstone }\end{array}$ & $\begin{array}{l}\text { Fine-grained sandstone } \\
\text { dominant, rarely } \\
\text { medium-grained } \\
\text { sandstone; well sorted }\end{array}$ & $\begin{array}{l}\text { Thinly- to very-thickly-bedded layers, } \\
\text { generally thickening upward. Thin shale } \\
\text { interbeds common. Small-to large-scale } \\
\text { planar, tangential, and trough cross- } \\
\text { stratification showing random } \\
\text { palaeocurrent directions. Reactivation } \\
\text { surfaces common; rip-up clasts occur }\end{array}$ & $\begin{array}{l}\text { Some brachiopod shell debris, } \\
\text { weak bioturbation }\end{array}$ & $\begin{array}{l}\text { Marar Fm. } \\
\text { very } \\
\text { common, } \\
\text { also } \\
\text { Assedjefar } \\
\text { Fm. }\end{array}$ & $\begin{array}{l}\text { Shallow } \\
\text { marine, upper } \\
\text { shoreface } \\
\text { environment }\end{array}$ \\
\hline $\begin{array}{l}\text { 7: Low-angle cross- } \\
\text { stratified sandstone }\end{array}$ & $\begin{array}{l}\text { Fine-grained sandstone, } \\
\text { well sorted }\end{array}$ & $\begin{array}{l}\text { Medium-bedded layers; sub-horizontal } \\
\text { lamination with low-angle discordances }\end{array}$ & Bioturbation absent & Marar Fm. & $\begin{array}{l}\text { Shallow } \\
\text { marine, } \\
\text { foreshore } \\
\text { environment }\end{array}$ \\
\hline $\begin{array}{l}\text { 8: Vertically burrowed } \\
\text { sandstone }\end{array}$ & $\begin{array}{l}\text { Fine-grained sandstone, } \\
\text { well sorted }\end{array}$ & $\begin{array}{l}\text { Thinly to medium-bedded layers. } \\
\text { Horizontal lamination }\end{array}$ & $\begin{array}{l}\text { Abundant up to } 10 \mathrm{~cm} \text { deep } \\
\text { vertical burrows (Skolithos) }\end{array}$ & Marar Fm. & $\begin{array}{l}\text { Shallow } \\
\text { marine, } \\
\text { shoreface and } \\
\text { foreshore }\end{array}$ \\
\hline $\begin{array}{l}\text { 9: Interference-ripple } \\
\text { sandstone }\end{array}$ & $\begin{array}{l}\text { Very-fine- to fine- } \\
\text { grained sandstone, well } \\
\text { sorted }\end{array}$ & $\begin{array}{l}\text { Very-thinly to medium-bedded layers, thin } \\
\text { shale interbeds. Symmetrical ripples, } \\
\text { interference ripples, asymmetrical ripples, } \\
\text { in-phase climbing ripples }\end{array}$ & $\begin{array}{l}\text { High surface bioturbation } \\
\text { (abundant grazing traces), rare } \\
\text { U-tubes with spreite } \\
\text { (Diplocraterion) }\end{array}$ & $\begin{array}{l}\text { Marar Fm., } \\
\text { Assedjefar } \\
\text { Fm. }\end{array}$ & $\begin{array}{l}\text { Shallow } \\
\text { marine, tidal } \\
\text { environment }\end{array}$ \\
\hline 10: Gypsiferous shale & $\begin{array}{l}\text { Shale with gypsum } \\
\text { crystals }\end{array}$ & $\begin{array}{l}\text { Gypsum enriched in laminae or } \\
\text { structureless }\end{array}$ & $\begin{array}{l}\text { Moderate pervasive } \\
\text { bioturbation }\end{array}$ & $\begin{array}{l}\text { Marar Fm. to } \\
\text { Dembaba } \\
\text { Fm. }\end{array}$ & $\begin{array}{l}\text { Shallow } \\
\text { marine, lagoon }\end{array}$ \\
\hline $\begin{array}{l}\text { 11: Lenticular-bedded } \\
\text { sandstone }\end{array}$ & $\begin{array}{l}\text { Fine-grained sandstone } \\
\text { lenses in gypsiferous } \\
\text { shale }\end{array}$ & Asymmetrical ripples & Weak bioturbation & $\begin{array}{l}\text { Assedjefar } \\
\text { Fm. }\end{array}$ & $\begin{array}{l}\text { Shallow } \\
\text { marine, tidal } \\
\text { environment }\end{array}$ \\
\hline $\begin{array}{l}\text { 12: Herring-bone } \\
\text { cross-stratified } \\
\text { sandstone }\end{array}$ & $\begin{array}{l}\text { Fine-grained sandstone, } \\
\text { well sorted }\end{array}$ & $\begin{array}{l}\text { Thinly-to medium-bedded layers. Planar } \\
\text { cross-stratification, preserved with } \\
\text { opposite palaeocurrent directions in } \\
\text { alternating beds }\end{array}$ & Weak bioturbation & Marar Fm. & $\begin{array}{l}\text { Shallow } \\
\text { marine, tidal } \\
\text { environment }\end{array}$ \\
\hline $\begin{array}{l}\text { 13: Unidirectional } \\
\text { trough cross- } \\
\text { stratified sandstone }\end{array}$ & $\begin{array}{l}\text { Fine- to medium- } \\
\text { grained sandstone, some } \\
\text { clay chips; very well } \\
\text { sorted }\end{array}$ & $\begin{array}{l}\text { Medium to very-thickly-bedded layers. } \\
\text { Trough cross-stratification, rarely } \\
\text { overturned cross-strata, load structures, } \\
\text { erosion surfaces common with clay chips } \\
\text { above }\end{array}$ & $\begin{array}{l}\text { Wood, up to } 25 \mathrm{~cm} \text { thick logs; } \\
\text { bioturbation absent }\end{array}$ & $\begin{array}{l}\text { Marar Fm., } \\
\text { Assedjefar } \\
\text { Fm. }\end{array}$ & $\begin{array}{l}\text { Downstream } \\
\text { migration of 3D } \\
\text { bedforms } \\
\text { within fluvial } \\
\text { channel }\end{array}$ \\
\hline $\begin{array}{l}\text { 14: Unidirectional } \\
\text { planar cross- } \\
\text { stratified sandstone }\end{array}$ & $\begin{array}{l}\text { Fine- to medium- } \\
\text { grained sandstone, some } \\
\text { clay chips; very well } \\
\text { sorted }\end{array}$ & $\begin{array}{l}\text { Medium to very-thickly-bedded layers. } \\
\text { Planar cross-stratification, some erosion } \\
\text { surfaces, soft-sediment deformation }\end{array}$ & $\begin{array}{l}\text { Wood, up to } 25 \mathrm{~cm} \text { thick logs; } \\
\text { bioturbation absent }\end{array}$ & $\begin{array}{l}\text { Marar Fm., } \\
\text { Assedjefar } \\
\text { Fm. }\end{array}$ & $\begin{array}{l}\text { Downstream } \\
\text { migration of 2D } \\
\text { bedforms } \\
\text { within fluvial } \\
\text { channel }\end{array}$ \\
\hline $\begin{array}{l}\text { 15: Cross-stratified } \\
\text { sandstone with } \\
\text { ripple-marks }\end{array}$ & $\begin{array}{l}\text { Fine- to medium- } \\
\text { grained sandstone, some } \\
\text { clay chips; well sorted }\end{array}$ & $\begin{array}{l}\text { Medium to thickly-bedded sandstone } \\
\text { layers with thin shale interbeds. Abundant } \\
\text { symmetrical ripples, some planar-, trough- } \\
\text { and tangential-cross-stratification, few } \\
\text { reactivation surfaces }\end{array}$ & $\begin{array}{l}\text { Wood fragments; bioturbation } \\
\text { absent }\end{array}$ & Marar Fm. & $\begin{array}{l}\text { Wave modified } \\
\text { fluvial deposits }\end{array}$ \\
\hline $\begin{array}{l}\text { 16: Plane-parallel } \\
\text { laminated } \\
\text { sandstone }\end{array}$ & $\begin{array}{l}\text { Fine- grained sandstone; } \\
\text { very well sorted }\end{array}$ & $\begin{array}{l}\text { Thinly to medium-bedded layers. Plane- } \\
\text { parallel lamination with parting lineation }\end{array}$ & $\begin{array}{l}\text { Rarely small wood fragments; } \\
\text { bioturbation absent }\end{array}$ & $\begin{array}{l}\text { Marar Fm., } \\
\text { Assedjefar } \\
\text { Fm. }\end{array}$ & $\begin{array}{l}\text { Upper flow } \\
\text { regime } \\
\text { deposition } \\
\text { within fluvial } \\
\text { channel }\end{array}$ \\
\hline
\end{tabular}


Table 1 (continued)

\begin{tabular}{|c|c|c|c|c|c|}
\hline Facies & Textures & Structures & Biota and bioturbation & $\begin{array}{l}\text { Stratigraphic } \\
\text { occurrence }\end{array}$ & Interpretation \\
\hline 17: Conglomerate & $\begin{array}{l}\text { Granules and pebbles; } \\
\text { poorly sorted }\end{array}$ & $\begin{array}{l}\text { Thinly to medium-bedded layers. Mostly } \\
\text { structureless, rarely soft-sediment } \\
\text { deformed }\end{array}$ & Some bone fragments & $\begin{array}{l}\text { Marar Fm., } \\
\text { Assedjefar } \\
\text { Fm. }\end{array}$ & $\begin{array}{l}\text { Deposition due } \\
\text { to } \\
\text { transgressive } \\
\text { reworking of } \\
\text { the shoreline }\end{array}$ \\
\hline $\begin{array}{l}\text { 18: Nodular calcareous } \\
\text { mudstone }\end{array}$ & $\begin{array}{l}\text { Rare shell fragments and } \\
\text { quartz grains in } \\
\text { calcareous matrix }\end{array}$ & $\begin{array}{l}\text { Thinly to thickly-bedded layers with } \\
\text { nodular appearance interbedded with } \\
\text { shales }\end{array}$ & Few shell fragments & $\begin{array}{l}\text { Dembaba } \\
\text { Fm. }\end{array}$ & $\begin{array}{l}\text { Marine low } \\
\text { energy } \\
\text { environment }\end{array}$ \\
\hline $\begin{array}{l}\text { 19: Hummocky cross- } \\
\text { stratified limestone }\end{array}$ & $\begin{array}{l}\text { Quartziferous wacke-/ } \\
\text { packstone }\end{array}$ & $\begin{array}{l}\text { Thinly to medium-bedded layers } \\
\text { interbedded with shales. Grading, } \\
\text { hummocky cross-stratification, convolute } \\
\text { bedding, symmetric ripples, erosive base }\end{array}$ & $\begin{array}{l}\text { Abundant shell fragments, } \\
\text { crinoidal debris. Some } \\
\text { gastropods, bryozoans, } \\
\text { foraminifera }\end{array}$ & $\begin{array}{l}\text { Dembaba } \\
\text { Fm. }\end{array}$ & $\begin{array}{l}\text { Marine storm } \\
\text { depositional } \\
\text { environment }\end{array}$ \\
\hline 20: Crinoidal limestone & $\begin{array}{l}\text { Grainstone to packstone, } \\
\text { poorly sorted }\end{array}$ & $\begin{array}{l}\text { Thinly to medium-bedded layers } \\
\text { interbedded with shales. Grading common }\end{array}$ & $\begin{array}{l}\text { Crinoidal debris (complete } \\
\text { stems up to } 8 \mathrm{~cm} \text { long), } \\
\text { brachiopods, shell fragments }\end{array}$ & $\begin{array}{l}\text { Dembaba } \\
\text { Fm. }\end{array}$ & $\begin{array}{l}\text { Marine } \\
\text { environment, } \\
\text { moderate to } \\
\text { high energy }\end{array}$ \\
\hline $\begin{array}{l}\text { 21: Bioclastic } \\
\text { grainstone }\end{array}$ & $\begin{array}{l}\text { Grainstone, rarely with } \\
\text { pebbles, poorly sorted }\end{array}$ & $\begin{array}{l}\text { Thinly bedded layers within shales. Grading } \\
\text { common }\end{array}$ & $\begin{array}{l}\text { Abundant brachiopods, } \\
\text { crinoids, gastropods, bryozoans; } \\
\text { rarely trilobites, solitary corals, } \\
\text { orthocone nautiloids. } \\
\text { Bioturbation absent }\end{array}$ & $\begin{array}{l}\text { Marar Fm., } \\
\text { Assedjefar } \\
\text { Fm., } \\
\text { Dembaba } \\
\text { Fm. }\end{array}$ & $\begin{array}{l}\text { Marine high } \\
\text { energy } \\
\text { environment; } \\
\text { possible storm } \\
\text { beds }\end{array}$ \\
\hline $\begin{array}{l}\text { 22: Cross-stratified } \\
\text { limestone }\end{array}$ & $\begin{array}{l}\text { Grainstone, moderately } \\
\text { sorted; some quartz } \\
\text { grains }\end{array}$ & $\begin{array}{l}\text { Medium-bedded layers. Planar cross- } \\
\text { stratification }\end{array}$ & $\begin{array}{l}\text { Abundant shell fragments, } \\
\text { brachiopods, crinoids, } \\
\text { gastropods; few rugose corals. } \\
\text { Bioturbation absent }\end{array}$ & $\begin{array}{l}\text { Lower } \\
\text { Assedjefar } \\
\text { Fm. }\end{array}$ & $\begin{array}{l}\text { Shallow marine } \\
\text { carbonate } \\
\text { shoal }\end{array}$ \\
\hline 23: Oolitic grain stone & $\begin{array}{l}\text { Grainstone, moderatly/ } \\
\text { well sorted. Abundant } \\
\text { ooids; some peloids, } \\
\text { quartz grains and mud } \\
\text { chips }\end{array}$ & Thinly to medium-bedded layers. Grading & $\begin{array}{l}\text { Abundant shell fragments, } \\
\text { crinoids, gastropods. Weak } \\
\text { bioturbation }\end{array}$ & $\begin{array}{l}\text { Assedjefar } \\
\text { Fm. }\end{array}$ & $\begin{array}{l}\text { Shallow } \\
\text { marine, high } \\
\text { energy } \\
\text { environment }\end{array}$ \\
\hline $\begin{array}{l}\text { 24: Ripple-laminated } \\
\text { limestone }\end{array}$ & $\begin{array}{l}\text { Packstone to grainstone, } \\
\text { well sorted. Some ooids, } \\
\text { peloids and extraclasts }\end{array}$ & $\begin{array}{l}\text { Thinly to medium-bedded layers. } \\
\text { Symmetrical ripples (ripple height between } \\
1-10 \mathrm{~cm} \text { ) often with bifurcations, } \\
\text { interference ripples }\end{array}$ & $\begin{array}{l}\text { Abundant shell fragments, } \\
\text { crinoids, gastropods, bryozoans; } \\
\text { few foraminifera. Weak } \\
\text { bioturbation }\end{array}$ & $\begin{array}{l}\text { Assedjefar } \\
\text { Fm., } \\
\text { Dembaba } \\
\text { Fm. }\end{array}$ & $\begin{array}{l}\text { Shallow marine } \\
\text { shoreface to } \\
\text { tidal } \\
\text { environment }\end{array}$ \\
\hline $\begin{array}{l}\text { 25: Stromatolitic } \\
\text { boundstone }\end{array}$ & $\begin{array}{l}\text { Bindstone; some } \\
\text { peloids, ooids and } \\
\text { quartz grains }\end{array}$ & $\begin{array}{l}\text { Thinly to thickly-bedded layers. Mostly SH- } \\
\text { type stromatolites, some LLH-type and } \\
\text { microbial laminites. Rarely symmetrical } \\
\text { ripples }\end{array}$ & $\begin{array}{l}\text { Microbial mats, few shell } \\
\text { fragments }\end{array}$ & $\begin{array}{l}\text { Top Marar } \\
\text { Fm., minor } \\
\text { Assedjefar } \\
\text { Fm., } \\
\text { Dembaba } \\
\text { Fm. }\end{array}$ & $\begin{array}{l}\text { Shallow marine } \\
\text { tidal/lagoonal } \\
\text { environment }\end{array}$ \\
\hline $\begin{array}{l}\text { 26: Oolitic sandstone } \\
\text { with analcite }\end{array}$ & $\begin{array}{l}\text { Very-fine-to fine- } \\
\text { grained sandstone; well } \\
\text { sorted }\end{array}$ & $\begin{array}{l}\text { Mostly structureless; rarely 'sigmoidal' } \\
\text { cross-stratification }\end{array}$ & non observed & $\begin{array}{l}\text { Middle } \\
\text { Dembaba } \\
\text { Fm. }\end{array}$ & \\
\hline $\begin{array}{l}\text { 27: Red mottled } \\
\text { siltstone }\end{array}$ & $\begin{array}{l}\text { Shale to very-fine- } \\
\text { grained sandstone; } \\
\text { poorly sorted }\end{array}$ & Mostly structureless, mottled appearance & Some rootlets & Marar Fm. & Palaeosol \\
\hline
\end{tabular}

olitic Beds') (Jakovljevic, 1984). The exact origin and depositional setting for this unit has yet to be determined.

\subsection{Tiguentourine Formation}

According to the $1: 10,00,000$ geological map of Libya, the only outcrop of this formation, which was first introduced by Lapparent and Lelubre (1948), is near B'ir Anzawa, close to the Algerian border (Fig. 1). There, it attains a maximum thickness of $23 \mathrm{~m}$ (Grubic et al., 1991). It comprises greenish and reddish-brown shales with some calcareous siltstones, and one approximately $6 \mathrm{~m}$ thick interval of gypsum and anhydrite.

Using subsurface well data the Tiguentourine Formation can be mapped throughout the subsurface of the Murzuq Basin and in the southern Ghadames Basin. In the northern Murzuq Basin, a thickness of $533 \mathrm{~m}$ was measured in well A1-73 (Hallett, 2002). The age of this formation, determined by Fabre (1970), ranges from Stephanian (Kasimovian, Gzhelian) to Asselian, suggesting it could extend into the lowermost Permian. Due to generally poor outcrops, this formation is difficult to study in the field and has not been analysed as part of this current research.

\section{Methods}

Sedimentary facies were studied in the outcrop by using traditional field sedimentary logging, both along transects and bedding planes. Due to the mild effects of the Hercynian Orogeny in this area, Carboniferous strata mostly have a very low dip angle and thus outcrop sections cover areas of many kilometres. To minimise error of thickness measurements, a Jacob's staff was used while 'walking out' the sections to measure meter intervals. Additionally, the thickness of the measured sections was verified by calculating the true thickness using bottom and top GPS locations and dip angle of the strata. Samples were collected for subsequent petrographic analysis. High resolution satellite images were used to assist in the field and augment information from the geological maps.

\section{Facies associations}

From the three outcrop locations Al Awaynat, Tinedhan and Awaynat Wanin (Fig. 1), 27 facies have been distinguished (Table 1 ), which can be grouped into four facies associations based on lithology, sedimentary structures, texture, palaeocurrent direc- 
tions, geometry and microfacies. The sedimentology of the facies associations is described and an interpretation of the depositional environment presented.

\subsection{Facies Association 1: offshore shales}

Facies Association 1 is dominated by green-beige coloured shales (Facies 1), which can reach a thickness of $90 \mathrm{~m}$. Due to low resistance to weathering, the shale successions are commonly expressed as geomorphological depressions and are often poorly exposed, especially where covered by Quaternary deposits. Where they crop out along hill slopes, horizontal lamination is observed. Rarely, poorly organised burrow systems are preserved.

Brown-black shales (Facies 2) have a maximum thickness of $8 \mathrm{~m}$ and are much less common than the green-beige shales. Bioturbation is absent in Facies 2.

Horizontally laminated siltstones between 1-5 cm thick (Facies 3 ), which sometimes show grading, are commonly intercalated in facies 1 , often with increasing frequency towards the top of the shale successions. Brachiopod shell fragments are sometimes concentrated at the base of the siltstone layers.

\subsubsection{Interpretation}

The occurrence of brachiopod fauna indicates a marine depositional environment for the shale successions. The thin siltstone layers are interpreted to be distal storm or event beds, transported into the offshore environment. The increasing frequency of siltstone layers towards the top of shale successions is interpreted to record a gradual shallowing upward.
The brown-black colour of some shale intervals was most-likely caused by the deposition of organic matter and preservation under oxygen-depleted conditions, also indicated by the absence of bioturbation.

\subsection{Facies Association 2: shallow marine clastics}

Facies Association 2 can be subdived into three units:

(a) Often found above Facies Association 1, Facies Association 2 comprises sandstones interbedded with shales. The sandstone beds frequently coarsen and thicken upward, with individual beds ranging from $5-40 \mathrm{~cm}$ in thickness. Their base is irregular and sometimes contains abundant brachiopod shell fragments. The most common sedimentary structure within the sandstone beds is hummocky cross-stratification (Facies 4, Fig. 3), which sometimes occurs above a graded interval. Swaley cross-stratification is less common and horizontal and ripple lamination are frequently observed. Pervasive bioturbation (e.g. Thalassinoides) is common, and occasional escape burrows can be found. The beds are grouped into 1$5 \mathrm{~m}$ thick depositional units.

(b) Facies Association 2 is also found either on top of hummocky cross-stratified sandstones or above shale successions. Ripple-laminated sandstones (Facies 5) occur, mostly overlain by multidirectional cross-stratified sandstones (Facies 6 ). Facies 5 consists of 3-25 cm thick layers, usually thickening upward. Symmetrical ripples, often bifurcated, show a high degree of surface bioturbation (grazing trails, see Fig. 3).
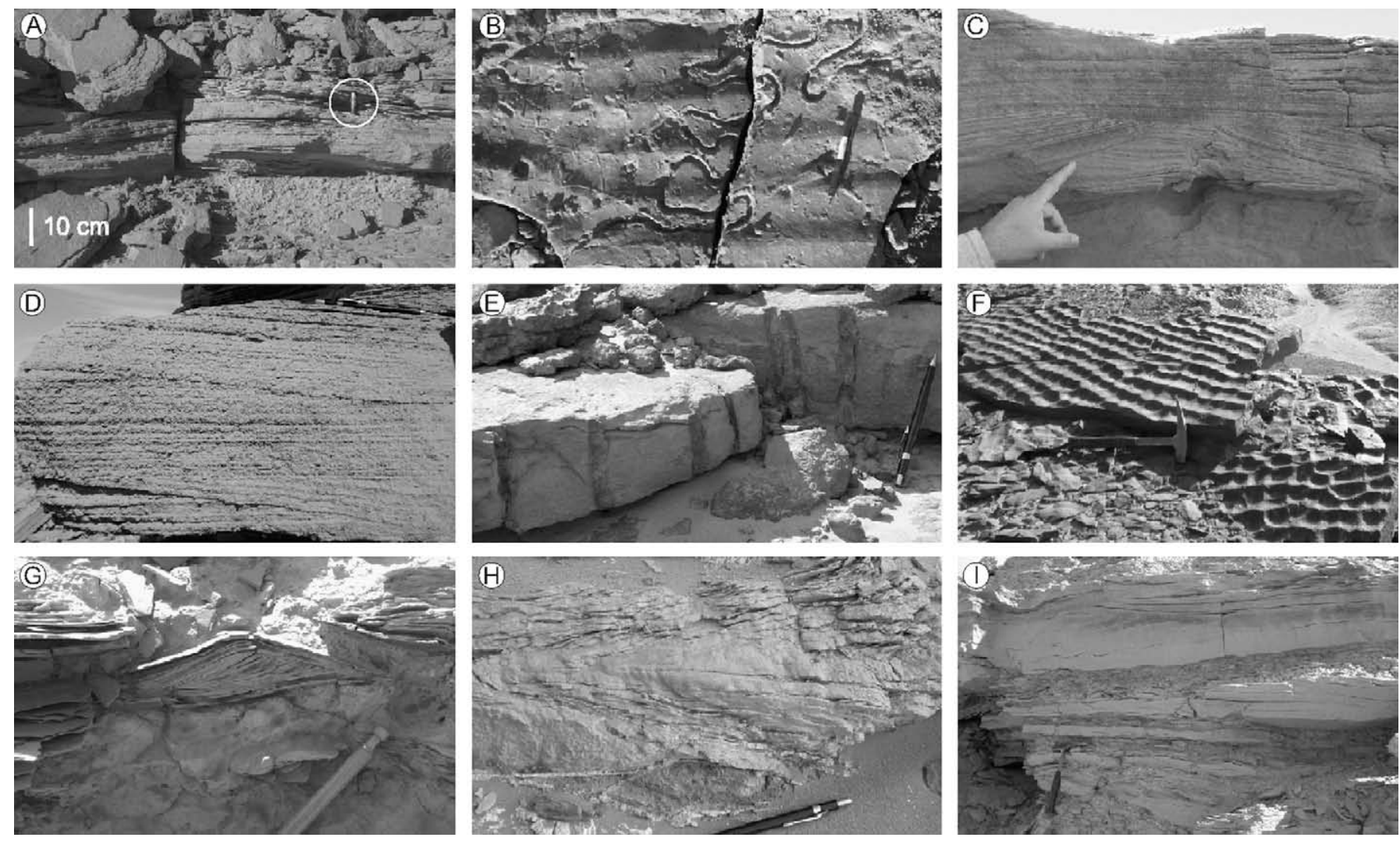

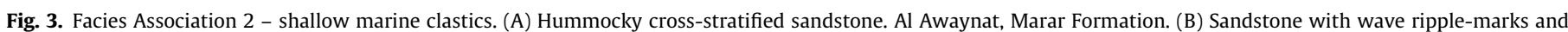

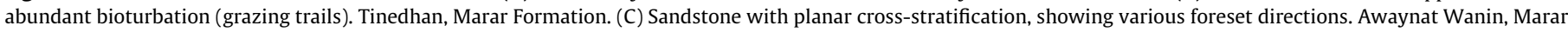

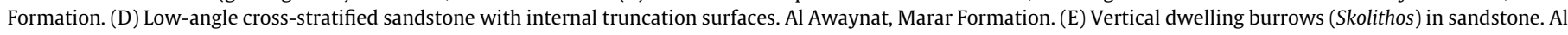

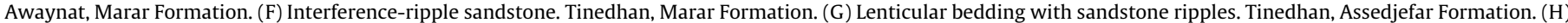

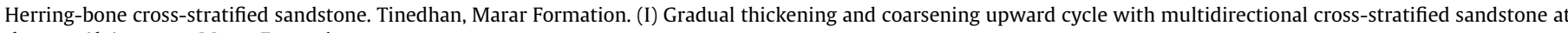
the top. Al Awaynat, Marar Formation. 
Facies 6 (ca. $10-150 \mathrm{~cm}$ thick layers) is usually more thickly bedded than Facies 5 and consists of mostly trough- and planar-cross-stratified sandstones with reactivation surfaces and multidirectional palaeocurrents. Some brachiopod and gastropod shell fragments occur, as well as a few mud ripup clasts. Bioturbation is generally limited. Within verythickly-bedded layers of Facies 6, channels rarely occur, approximately $1 \mathrm{~m}$ thick and $5 \mathrm{~m}$ wide. The base of the channel is marked by a pebble lag, followed by large-scale trough cross-stratified fine-grained sandstone, often with symmetrical ripples towards the top. Facies 5 and 6 are common and often occur together within the same depositional unit ( $30 \mathrm{~cm}$ to $8 \mathrm{~m}$ thick), which can be followed in the outcrop laterally over long distances $(>20 \mathrm{~km})$ without any notable facies change.

Low-angle cross-stratified sandstones (Facies 7) are a less common facies. Beds are $20-40 \mathrm{~cm}$ thick and comprise sub-horizontally laminated sets $(5-15 \mathrm{~cm}$ thick), separated by low-angle discordances (Fig. 3). Bioturbation is absent. This facies sometimes occurs above multidirectional crossstratified sandstones (Facies 6).

Vertically burrowed sandstones (Facies 8 ) rarely occur. The mostly $10-20 \mathrm{~cm}$ thick layers are penetrated by numerous Skolithos burrows.

(c) A common facies within Facies Association 2 is Facies 9 which consists of interference-rippled (ladder-rippled) sandstones. Symmetrical ripples with parallel crests occur together with a second generation of slightly smaller ripples with a crest angle at approximately $90^{\circ}$ to the first (Fig. 3 ). Abundant grazing trails are preserved on the surface of the layers. Thickness of the sandstone beds vary from $3-30 \mathrm{~cm}$. Gypsiferous shales (Facies 10), often associated with lenticular-bedded sandstones (Facies 11) and herring-bone crossstratified sandstones (Facies 12), are a less common facies. Facies 11 consists of $3-7 \mathrm{~cm}$ thick and $10-15 \mathrm{~cm}$ wide sandstone lenses within the shales, displaying cross-lamination (Fig. 3). Facies 12 is made of $15-30 \mathrm{~cm}$ thick sandstone layers, which are planar and tangential cross-stratified. Adjacent sets within the layers often have bipolar palaeocurrent directions (Fig. 3). Shale layers between the sandstones range from $0.5-3 \mathrm{~cm}$ thick. While Facies 9 can often be followed laterally over several hundred meters, both Facies 11 and 12 are laterally more restricted and rarely extend for more than $40 \mathrm{~m}$.

\subsubsection{Interpretation}

The nine different facies types present within Facies Association 2 are interpreted to be deposited under shallow marine conditions (Facies 4-12). These can be further subdivided into distal to proximal settings, with: (a) storm related deposits, (b) shoreline deposits, and (c) tidal deposits.

(a) Hummocky and swaley cross-stratification are bedforms which typically form during storm conditions between the fair weather and the storm wave base, whereby the swaley cross-stratification is deposited in slightly shallower water relative to the hummocky cross-stratification (Dumas and Arnott, 2006). The irregular, erosive base of sandstone layers and presence of escape burrows indicate rapid deposition in a high energy environment. The coarsening and thickening upward of individual beds suggests increase in energy and shallowing of the environment, interpreted to reflect deposition dominantly during relative sea-level fall.

(b) Bifurcated symmetrical ripples with a high degree of bioturbation typically occur in shallow marine environments above fair-weather wave base. The ripple-laminated sandstones, showing a gradual transition to planar and trough cross-stratified sandstones, are interpreted as lower shoreface deposits. Multidirectional palaeocurrents and the occurrence of bioturbation and brachiopod shell fragments suggest an upper shoreface environment of the latter. Channel bodies, which sometimes occur within these shoreface deposits, are interpreted as small tidal inlet channels.

Sub-horizontally laminated sandstones with low-angle truncation surfaces are interpreted as foreshore deposits. In modern beach environments, these structures develop in the swash zone, landward of the shoreface environment (e.g. Reineck and Singh, 1980).
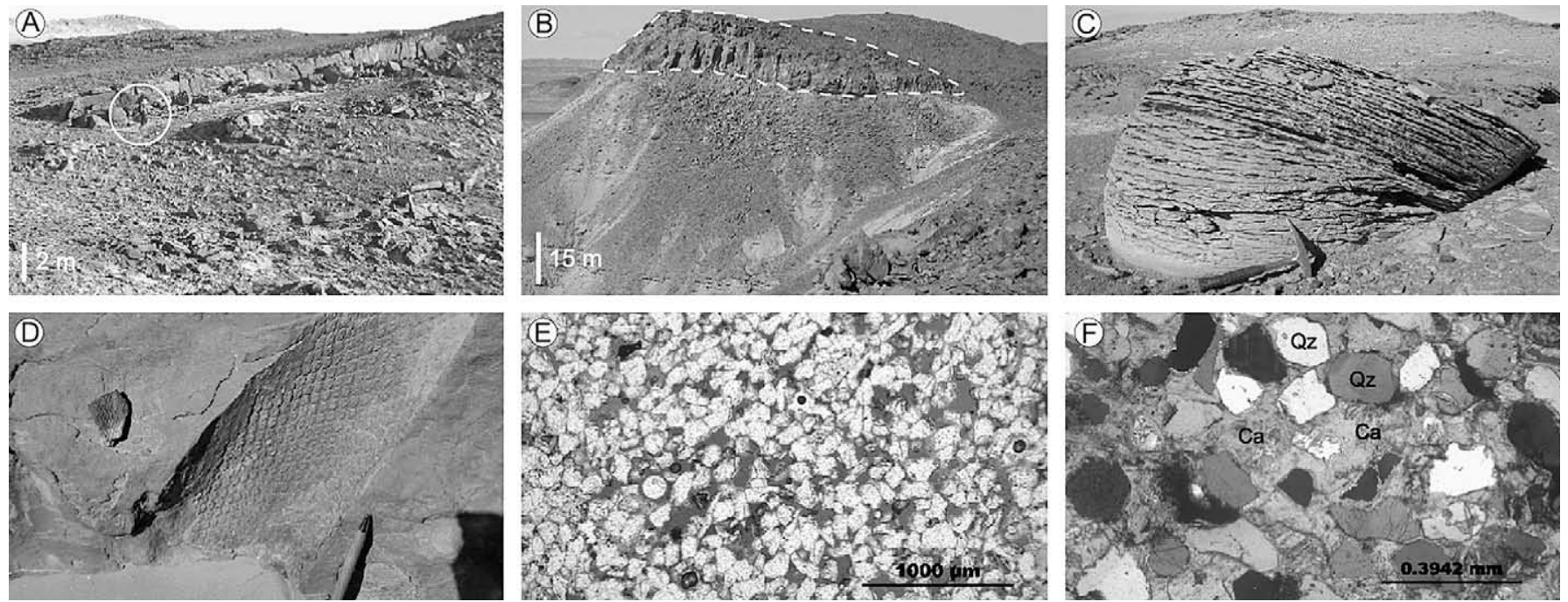

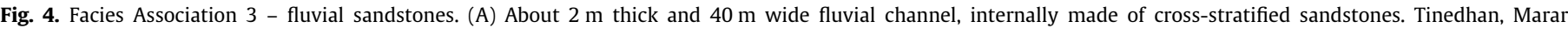

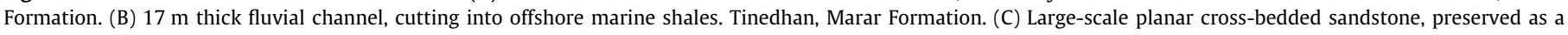

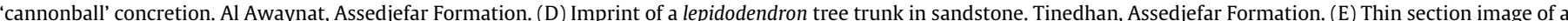

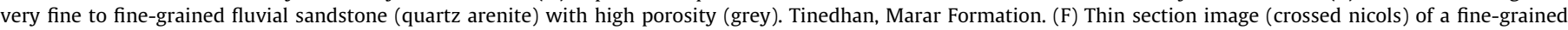
fluvial sandstone without porosity due to carbonate cementation. Qz: Quartz; Ca: Calcite. Tinedhan, Assedjefar Formation. 
(c) Interference ripples, which are common structures, formed due to the interaction of waves and currents in tidal environments (e.g. Makhlouf, 2000). Lenticular bedding can occur in a variety of depositional environments, including marine delta front, channel-mouth facies, and tidal environments (Reineck and Singh, 1980). The association with gypsiferous shales suggest a tidal, possibly Sabkha depositional environment, further supported by the presence of herring-bone cross-stratified sandstones, formed due to the reversal of palaeocurrent directions between ebb and flood tide.

\subsection{Facies Association 3: fluvial sandstones}

This facies association is made up of lenticular/channelized sandbodies which vary in thickness from $1.5 \mathrm{~m}$ (ca. $40 \mathrm{~m}$ wide) to $50 \mathrm{~m}$ (ca. $1.5 \mathrm{~km}$ wide). All the sandbodies are characterised by an erosive base. The sandstones are fine- to medium-grained quartz arenites and vary from being completely calcite cemented to highly porous and weakly cemented (Fig. 4). The sandstones exhibit trough (Facies 13) and planar cross-stratication (Facies 14), which make up the bulk of the sedimentary structures observed, with the latter facies being slightly dominant. Individual cross-bed sets are $0.5-1 \mathrm{~m}$ thick on average, but can reach a maximum of $1.5 \mathrm{~m}$. Some overturned cross-strata and load structures occur. Several internal erosion surfaces occur within the sandstone bodies, often associated with $\mathrm{cm}$ sized mud clasts at the base. Cross-stratified sandstones with ripple-marks (Facies 15) and plane-parallel laminated sandstones (Facies 16) with parting lineation occur rarely.

Bioturbation is absent in all the lenticular sandbodies. Plant fragments are common, especially casts of lycopsid axes (MeyerBerthaud, pers. comm.) and fragments of Lepidodendron (Fig. 4).

Palaeocurrent directions derived from the planar and trough cross-strata vary within single sandbodies by up to $100^{\circ}$, but usually $40-60^{\circ}$. The dominant palaeocurrent direction of lenticular sandbodies thicker than $15 \mathrm{~m}$ is towards the northwest; that of individual sandstone bodies thinner than $15 \mathrm{~m}$ shows a larger range of flow directions (Fig. 9).

\subsubsection{Interpretation}

The channel shape morphology of the sandstone bodies, the presence of an erosive base and cross-bedding, together with the absence of bioturbation and the occurrence of land plant fragments indicate sandstone deposition in fluvial channels. Unidirectional trough (Facies 13) and planar cross-stratified sandstones (Facies 14) were deposited within the fluvial channel as 3D and 2D bedforms, respectively. Plane-parallel laminated sandstones (Facies 16) with parting lineation formed in the upper flow regime as plane beds. Overturned cross-stratification indicates that river currents with high shear strengths deformed the soft sediment (Owen, 1996). The occurrence of erosion surfaces within the lenticular sandstone bodies shows that multiple events of erosion and deposition filled the channels.

A dominant palaeocurrent direction towards the northwest is interpreted for the fluvial system in western Libya during the Early Carboniferous. The variation of palaeoflow directions within smaller channels could record higher sinuosity smaller rivers feeding the main fluvial drainage network.

The abundant occurrence of arborescent lycopsids indicates that a wet or humid climate prevailed in western Libya during the Early Carboniferous (Meyer-Berthaud, pers. comm.).

\subsection{Facies Association 4: marine carbonates}

All deposits of this facies association within the investigated area are made up of laterally continuous very thinly to thickly-bed- ded carbonates (both limestones and dolomites, dominantly thinly to medium bedded) interbedded with shales. No carbonate buildups were observed.

Facies Association 4 can be divided into three units:

(a) Hummocky cross-stratified limestones (Facies 19) with an irregular base frequently occur. They are normally graded sometimes occuring in fining and thinning upward cycles, and composed of coarse crinoidal debris with occasional shell fragments at the base. The beds display hummocky cross-stratification, convolute bedding and ripple lamination towards the top. Crinoidal limestones (Facies 20), usually have a blue colour at outcrop, and mostly consist of poorly sorted crinoid ossicles (Fig. 5) including up to $10 \mathrm{~cm}$ long complete crinoid stems. Petrographic analysis indicates that Facies 20 can mostly be classified as a packstone, more rarely as a grainstone. Poikilotopic cements are associated with the crinoid fragments, porosity was not observed. Facies 21 is made of thinly bedded and often graded bioclastic grainstones, consisting of fragments of a variety of biota (brachiopods, crinoids, gastropods, bryozoans, and sometimes trilobites, solitary ruguse corals and orthocone nautiloids). It is a very common facies in Carboniferous deposits throughout the investigated area.

(b) Cross-stratified limestones (Facies 22) with up to $30 \mathrm{~cm}$ thick sets of planar cross-stratification are a very rare facies (Table 1). They overlie Facies 23 (oolitic grainstones): peloids, quartz grains and mud chips are admixed to the dominant ooid composition. Normal grading sometimes occurs. Ripple-laminated limestone is often preserved (Facies 24). Symmetrical ripples with a ripple height between 1-10 cm (Fig. 5) occur, interference ripples are also preserved. Ooids, peloids and extraclasts (Fig. 5) are common constituents of these pack- to grainstones, together with shell fragments, crinoid ossicles, gastropods, bryozoans and few foraminifera.

(c) Stromatolitic boundstones (Facies 25) usually consist of SH-type (stacked hemispheroids) stromatolites (Collenia) (Freulon, 1953) with diameters of up to $1 \mathrm{~m}$; rarely some thinly bedded microbial laminites occur. Facies 10 (gypsiferous shales) and 23 (oolitic grainstones) are closely associated with Facies 25. Nodular calcareous mudstones (Facies 18), mostly thinly bedded with thick shale interbeds, are usually devoid of fossils or sedimentary structures. Rarely, birds-eyes structures and convolute bedding occur.

\subsubsection{Interpretation}

Facies Association 4 is made up of 8 facies types (Facies 18-25), which can be grouped according to depositional environment into: (a) storm related deposits, (b) shoreline deposits, and (c) tidal deposits. These are similar environments of deposition to those of the shallow marine clastics of Facies Association 2.

(a) The occurrence of grading, hummocky cross-stratification (HCS), convolute bedding and ripple lamination (Facies 19) within one bed is typically interpreted to be the product of storm events. HCS often forms slightly above the storm wave base. The usually fragmented fossils and the grading within bioclastic grainstones (Facies 21) indicates, together with their common intercalation in shales, that high energy events like major storms reworked the shallow water organisms and transported them away from the shore into a more distal environment. 

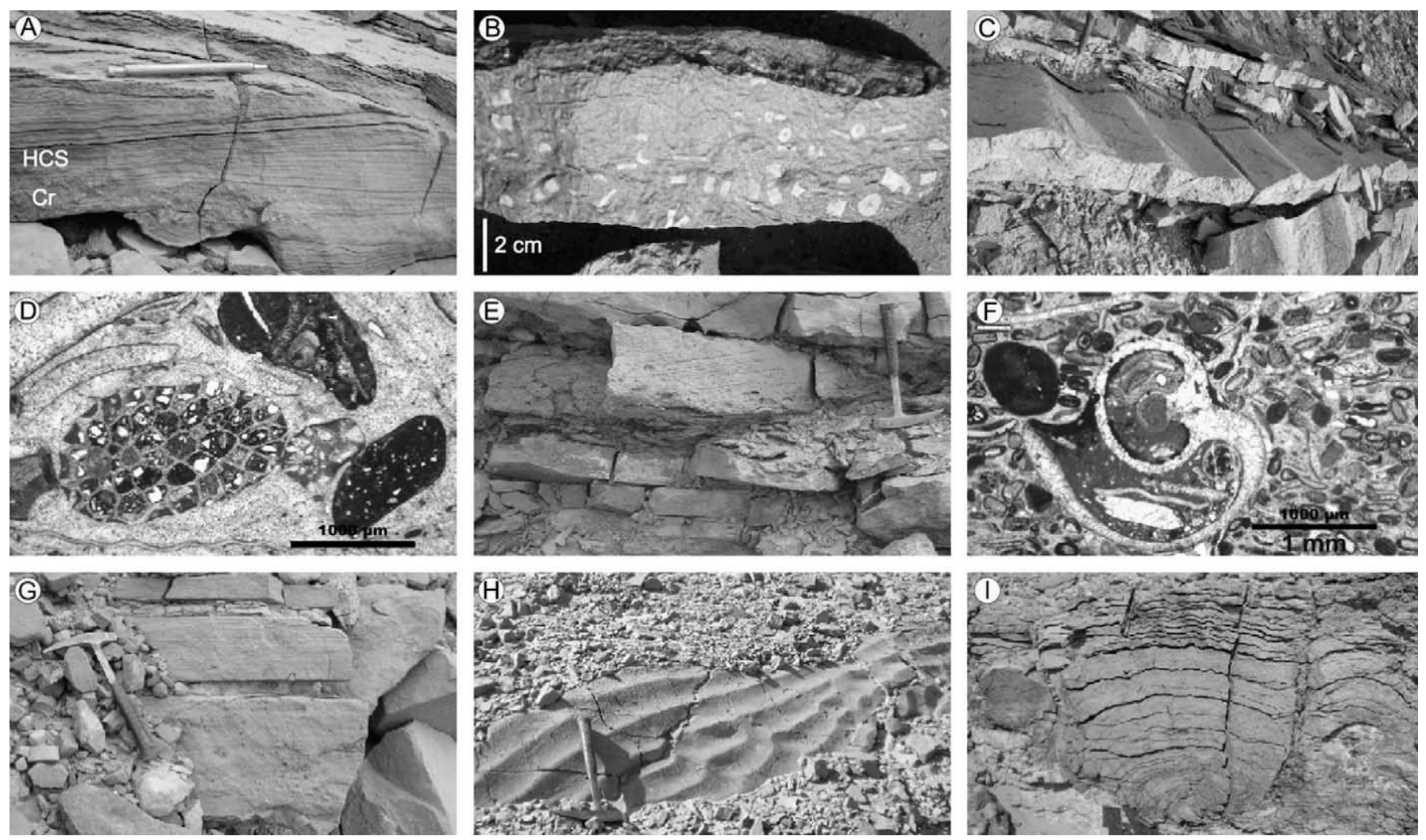

Fig. 5. Facies Association 4 - marine carbonates. (A) Limestone layer with graded crinoidal debris ( $\mathrm{Cr}$ ) at the base and hummocky cross-stratification (HCS) above. Tinedhan, Dembaba Formation. (B) Limestone consisting of large crinoid ossicles. Al Awaynat, Dembaba Formation. (C) Limestone layer with large wave ripples. Tinedhan, Assedjefar Formation. (D) Thin section image of a sample taken from the limestone layer shown in (C). Dark extraclasts made of shale, quartz grains and a bryozoan fragment occur in a grainstone with abundant shell fragments. (E) Thickening and coarsening upward cycle of limestone layers with a planar cross-stratified limestone at the top. Tinedhan, Assedjefar Formation. (F) Thin section image of a sample taken from the limestone layer (grainstone) shown in the centre of (E). A gastropod fragment filled with shale and some quartz grains occurs within abundant calcite cemented ooids and some peloids. (G) Thinning and fining upward cycle of limestone layers (wackestones and packstones). Tinedhan, Dembaba Formation. (H) Wave ripple-marks with bifurcations on top of a limestone layer. Tinedhan, Dembaba Formation. (I) LLH-type stromatolites (Collenia). Awaynat Wanin, top Marar Formation.

The depositional environment of the crinoidal limestones (Facies 20) is less easily constrained. While today crinoids usually live in deep oceans, their primary habitat during the Palaeozoic probably was much shallower, on the shelf (Flügel, 2004). As the crinoidal limestiones are associated with Facies 20, which are grainstones with grading, a marine high energy environment is interpreted. As such, some of the crinoidal limestones are interpreted to be storm beds.

(b) Facies 22-24 are interpreted as shallow marine shoreline deposits based on the occurrence of symmetrical ripples with bifurcations, providing evidence of wave action, planar cross-stratification within carbonate sands, interpreted as possibly carbonate shoals, and the presence of ooids, which were dominantly formed in very shallow marine waters.

(c) Stromatolites and microbialites have been described from a variety of depositional environments, from supratidal to deeper water (Leinfelder and Schmid, 2000); however they dominantly form in intertidal and lagoonal environments. The stromatolites in the investigated area (Facies 25) often occur together with rippled sandstones and carbonates with ooids as well as gypsiferous shales; hence they probably inhabited a lagoonal environment.

Nodular calcareous mudstones (Facies 18) were deposited in a low energy marine environment. The rare occurrence of birds-eye structures indicates that parts of Facies 18 were deposited in an intertidal environment.

In Table 1, two facies are described which cannot be placed in one of the facies associations: Facies 26 (oolitic sandstone with analcite) and Facies 27 (Red mottled siltstone). The former facies was already mentioned by previous authors (e.g. Jakovljevic, 1984) (see Sections 2.4 and 5.2.3); its depositional environment cannot yet be clearly determined. Facies 27 has a red, structureless to mottled appearance with rootlets and is interpreted as a palaeosol, indicative of long-term subaerial exposure.

\section{Outcrop descriptions}

\subsection{Tinedhan (N $27^{\circ} 10^{\prime} 51^{\prime \prime}$ E $\left.9^{\circ} 56^{\prime} 46^{\prime \prime}\right)$}

\subsubsection{Marar Formation}

In the Tinedhan Anticline, the Marar Formation attains a total measured thickness of $470 \mathrm{~m}$ (Fig. 6). The basal contact with the underlying formation could not be confirmed, but correlation with a biostratigraphically dated Carboniferous section from the Illizi Basin close to Tinedhan (Coquel and Massa, 1993) suggests that the logged interval represents a complete Marar Formation.

The main facies associations are offshore shales (FA 1) and shallow marine clastics (FA 2), the latter dominated by hummocky cross-stratified sandstones (Facies 4). Typical cycles are 5-20 m thick, comprising alternations of gradual coarsening and thickening upward sandstone and green-beige shale. The top of each cycle is mostly represented by Facies 4, less often by ripple-laminated sandstones of Facies 5. Within the Marar Formation in Tinedhan three distinct stratigraphic horizons occur with 15-50 m thick channelised bodies filled with fluvial sandstones (FA 3). The channels erosively cut down into offshore shales and hummocky cross- 


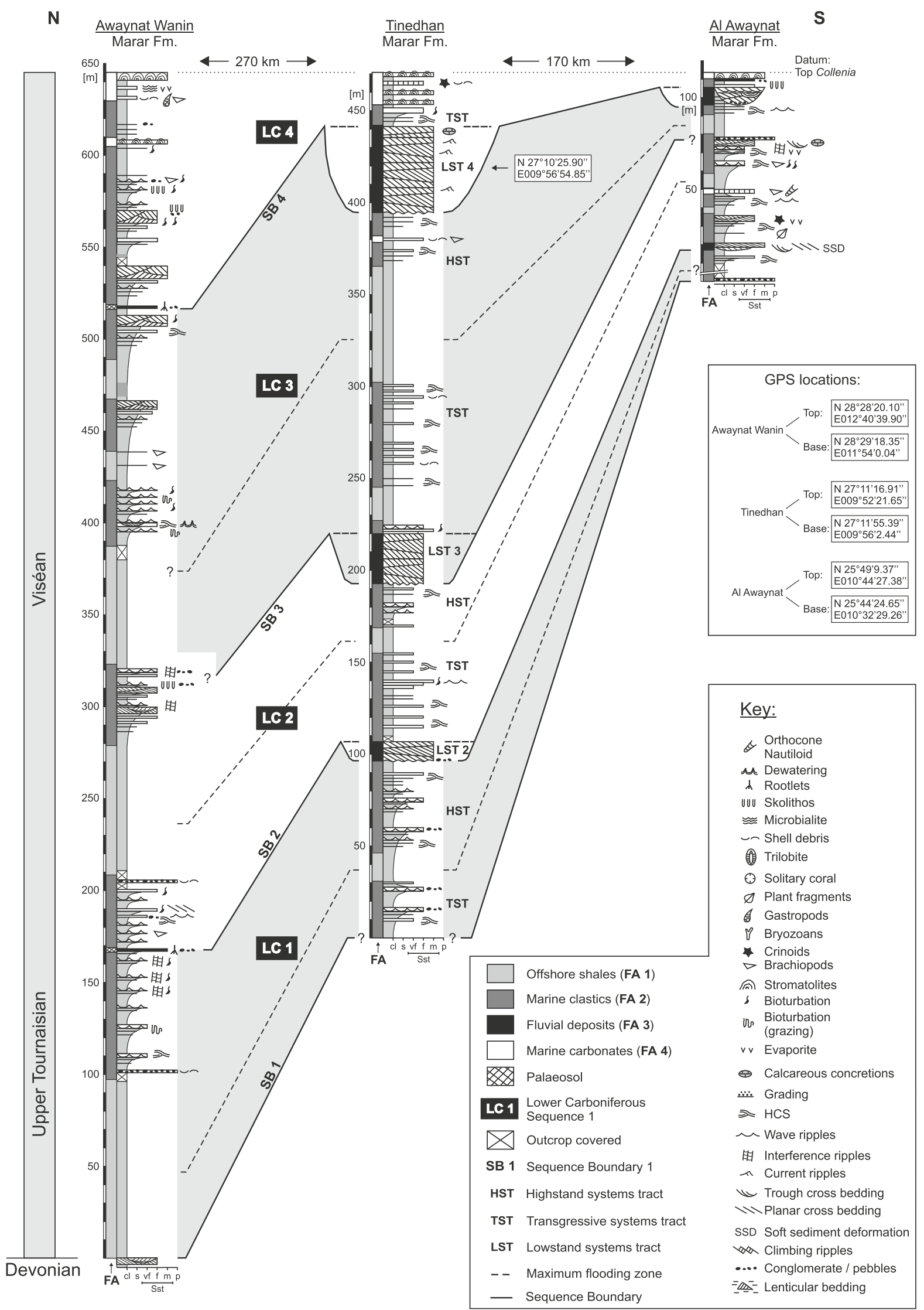

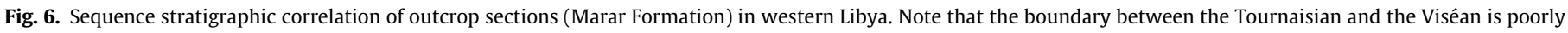
defined. For location of sections see Fig. 1. 
stratified sandstones. Laterally, the channel sandstones wedge out (Fig. 8) and shales overlying the channel directly rest on shales from below the channel. Marine carbonates (FA 4) are very rare and occur as $5-20 \mathrm{~cm}$ thick bioclastic grainstones (Facies 21 ), dominated by brachiopods. Below the Collenia beds, the youngest fluvial sandstone horizon forms a several kilometre large field of carbonate cemented concretions up to $2 \mathrm{~m}$ in diameter.

\subsubsection{Assedjefar Formation}

The transition from the Marar to the Assedjefar Formation is conformable and only defined by the occurrence of the Collenia beds. The transition to the Dembaba Formation similarly is conformable, however less clearly defined. Grubic et al. (1991) used a stromatolitic limestone as a marker for the base of the Dembaba Formation, but mentioned that this horizon occurs only locally. In Tinedhan, the top of the Assedjefar Formation is placed at the base of a thick shale succession, which is in accordance with the biostratigraphically dated section of Coquel and Massa (1993). The Assedjefar Formation is $220 \mathrm{~m}$ thick and comprises dominantly shallow marine clastics (FA 2); however there is a gradual increase in the number of intercalations of marine carbonates (FA 4) to- wards the top (Fig. 7). Thinly bedded bioclastic grainstones (Facies 21 ) are very common. Hummocky cross-stratified limestones (Facies 19) and ripple-laminated limestones (Facies 24) occur for the first time within the Carboniferous succession in the upper Assedjefar Formation.

About $30 \mathrm{~m}$ above the Collenia beds, several fluvial channel sandstones (FA 3) occur at one stratigraphic horizon. These are usually a few meters thick and include one $24 \mathrm{~m}$ thick channel. Large carbonate concretions are abundant. Approximately $70 \mathrm{~m}$ higher in the stratigraphic column, an approximately $2 \mathrm{~m}$ thick fluvial channel occurs, which represents the youngest fluvial facies in the Carboniferous succession.

\subsubsection{Dembaba Formation}

The Dembaba Formation has a minimum measured thickness of $140 \mathrm{~m}$ in Tinedhan (Fig. 7). The transition to the Tiguentourine Formation is overlain by Quaternary deposits and thus could not be identified. The lower half of the Dembaba Formation consists of offshore shales (FA 1) with a few very thinly bedded siltstone layers. The upper half is made of an alternation of blue limestone and shale layers, sometimes arranged in thinning upward cycles

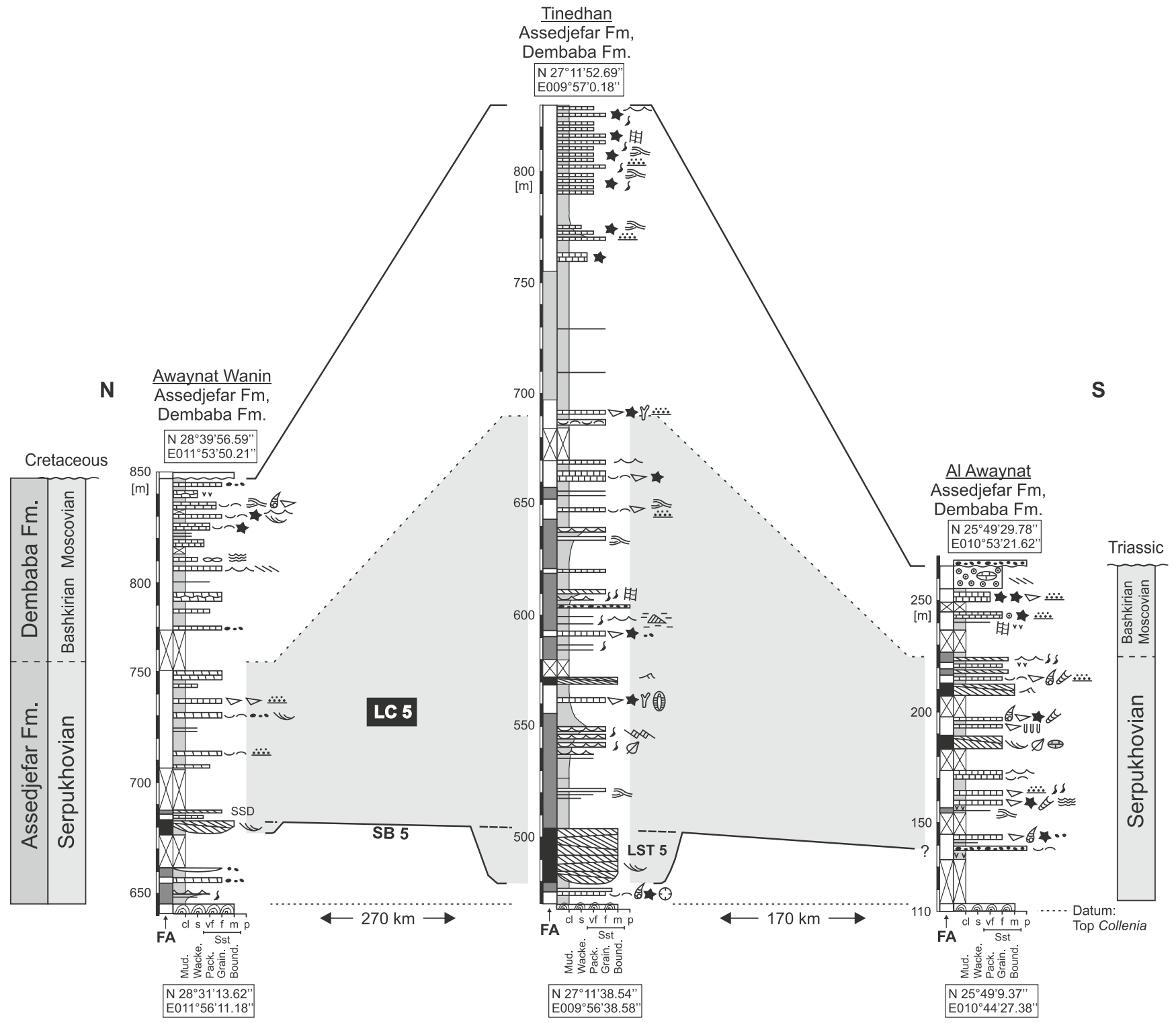

Fig. 7. Sequence stratigraphic correlation of outcrop sections (Assedjefar and Dembaba Formation) in western Libya. For location of sections see Fig. 1; key as in Fig. 6. 
(Fig. 5). The carbonates are dominated by hummocky cross-stratified limestones (Facies 19), crinoidal limestones (Facies 20), and ripple-laminated limestones (Facies 24).

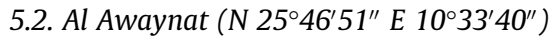

\subsubsection{Marar Formation}

According to Jakovljevic (1984), the Marar Formation unconformably overlies the Middle Devonian Ouan Kasa Formation in the area of Al Awaynat. From the basal red conglomerate layer to the top of the Collenia beds, the Marar Formation has a thickness of $115 \mathrm{~m}$ (Fig. 6). Shallow marine clastics (FA 2) are by far the most dominant lithology, forming thickening upward cycles similar to those in Tinedhan, the main difference being that ripple-laminated sandstones (Facies 5) and multidirectional cross-stratified sandstones (Facies 6) usually occur at the cycle tops. Hummocky cross-stratified sandstones (Facies 4 ) are less prominent.

Fluvial sandstones (FA 3) occur only as thin, about $1.5 \mathrm{~m}$ thick channels approximately $20 \mathrm{~m}$ above the base of the formation and as more prominent, $5-10 \mathrm{~m}$ thick channels close to the top (Fig. 8). Only one limestone layer occurs in the middle Marar Formation, represented by a bioclastic grainstone (Facies 21).

\subsubsection{Assedjefar Formation}

The Assedjefar Formation is about $110 \mathrm{~m}$ thick in the vicinity of Al Awaynat. It is mostly made up of marine carbonates (FA 4), some shallow marine clastics (FA 2) and two horizons with fluvial sandstones (FA 3) (Fig. 7). Almost all the carbonate layers are characterised by bioclastic grainstones (Facies 21), with less common ripple-laminated limestones (Facies 24) in the middle part of the Assedjefar Formation. The outcrop of the fluvial sandstones, which both occur in the upper half of the formation, is poor; typical channel shape or erosive base could not be identified. Large "cannon ball' concretions are well preserved (Fig. 4).

\subsubsection{Dembaba Formation}

The Dembaba Formation is about $40 \mathrm{~m}$ thick near Al Awaynat, and consists of marine carbonates (FA 4) in the lower part and oolitic sandstones with analcite (Facies 26) in the upper part. The carbonates are made of oolitic grainstones (Facies 23) and blue coloured crinoidal limestones (Facies 20), the latter containing abundant decimetre long and up to $2 \mathrm{~cm}$ wide crinoid stems. Facies 26, called the 'Dembaba Analcimolitic Beds' by previous authors, has a conspicuous orange-yellow colour and mostly appears structureless in the outcrop. Several modes of formation have been discussed for this lithology, including the interaction of sodium-rich brackish waters with volcanic ash (see review in Jakovljevic, 1984). Cross-bedded sandstones of the Triassic Zarzaitine Formation unconformably overly the 'Analcimolitic Beds'. According to Grubic et al. (1991), limestones of the Dembaba Formation overly the 'Analcimolitic Beds' north of Al Awaynat, proving their Late Carboniferous age.

\subsection{Awaynat Wanin (N $28^{\circ} 29^{\prime} 33^{\prime \prime}$ E $\left.12^{\circ} 41^{\prime} 15^{\prime \prime}\right)$}

\subsubsection{Marar Formation}

According to biostratigraphic data from wells close to Awaynat Wanin (Massa et al., 1980), the base of the Marar Formation is of late Tournaisian age and overlies late Famennian deposits. In the outcrop, a thickness of $650 \mathrm{~m}$ was measured from the base, located using the geological 1:2,50,000 map of Libya (Gundobin, 1985), to the top of the Collenia unit (Fig. 6). The latter is made of four stromatolitic horizons within an approximately $40 \mathrm{~m}$ thick succession. The Marar Formation in the area of Awaynat Wanin is exclusively made up of an alternation of offshore shales (FA 1) and shallow marine clastics (FA 2). The shale successions, up to $100 \mathrm{~m}$ thick in the lower part of the formation, are dominated by green-beige shales (Facies 1 ). Up to $10 \mathrm{~m}$ thick brown-black shales (Facies 2) were also found within the upper half of the Marar Formation.

The shallow marine clastics form about 5-30 m thick gradual coarsening and thickening upward cycles, typically with hummocky cross-stratified sandstones (Facies 4) at the base, followed by ripple-laminated sandstones (Facies 5 ) with abundant bioturbation. These are the most prominent facies of the Marar Formation around Awaynat Wanin. Up to $3 \mathrm{~m}$ thick multidirectional crossstratified sandstones (Facies 6) commonly form the cycle tops. These cycles are laterally very persistent (Fig. 8) and can be followed in the outcrop for over $20 \mathrm{~km}$. Fluvial channel sandstones, which occur both in Al Awaynat and Tinedhan, were not observed. However, two horizons of red mottled siltstones with rootlets (Facies 27) interpreted to be palaeosols, occur in the lower and upper half, respectively, and these could be correlative with the channel sandstones (Fig. 6).

\subsubsection{Assedjefar Formation}

The boundary between the Assedjefar and the Dembaba Formation in Awaynat Wanin is defined using biostratigraphic data from Massa et al. (1980) and Berendeyev (1985). A thickness of $110 \mathrm{~m}$ was measured in the outcrop. The lower half consists of shallow marine clastics (FA 2), which are dominated by ripple-laminated sandstones (Facies 5) and mostly dolomitised marine carbonates (FA 4), interbedded with green-beige shales (Facies 1). Approximately $35 \mathrm{~m}$ above the Collenia unit, a $5 \mathrm{~m}$ thick fluvial channel sandstone occurs (Fig. 7). The upper half exclusively consists of marine carbonates (FA 4), represented by bioclastic grainstones (Facies 21) with abundant brachiopods and some structureless dolomite layers.

\subsubsection{Dembaba Formation}

The Dembaba Formation is $95 \mathrm{~m}$ thick and unconformably overlain by the Cretaceous Mizdah Formation. The entire Dembaba Formation at Awaynat Wanin consists of marine carbonates (FA 4), which are represented by a variety of facies types (nodular calcareous mudstones, hummocky cross-stratified limestones, crinoidal limestones, bioclastic grainstones, cross-stratified limestones and ripple-laminated limestones). The mostly thinly to medium bedded, sometimes dolomitised carbonate layers are interbedded with up to $7 \mathrm{~m}$ thick green-beige shales (Facies 1 ).

\section{Lower Carboniferous sequences}

The sequence stratigraphic framework for Carboniferous deposits in western Libya, as shown in Figs. 6 and 7 is explained and discussed in Section 7.1. The vertical and lateral development of Lower Carboniferous sequences (LC 1-5) is briefly described in the following section.

\subsection{Lower Carboniferous sequence 1 (LC 1)}

In Awaynat Wanin, basal Carboniferous deposition starts with a ca. $100 \mathrm{~m}$ thick offshore shale succession, which is followed by numerous, relatively thin shallowing upward cycles with abundant wave and interference-rippled sandstones on top (Fig. 6). The latter are interpreted as very shallow marine to tidal deposits. The turnaround point from transgression to regression within LC 1 is placed within the thick shale succession; the trend towards a shallower depositional environment culminates in subaerial exposure and the development of a palaeosol on top of LC 1 .

Towards Tinedhan and Al Awaynat, LC 1 is thinning considerably. Here, unlike Awaynat Wanin, the basal transgressive part includes shallowing upward cycles with shallow marine clastics at 

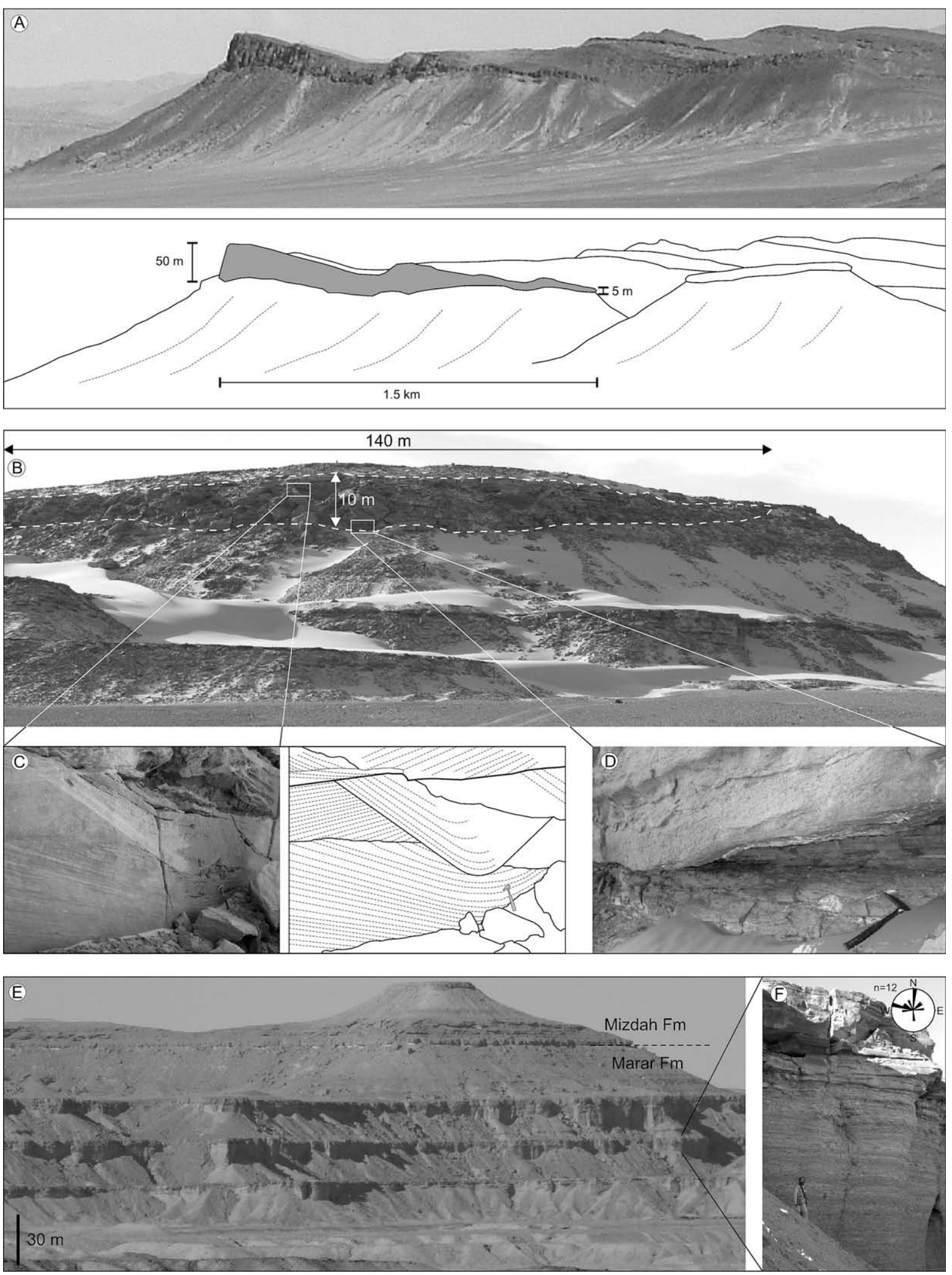

Fig. 8. Outcrop images of the Marar Formation in western Libya. (A) A $50 \mathrm{~m}$ thick channel, filled with cross-stratified fluvial sandstones, shows a lateral thickness reduction to $5 \mathrm{~m}$ within a distance of $1.5 \mathrm{~km}$. The base of the channel overlies offshore shales with an erosional unconformity and is interpreted as a sequence boundary. The fluvial sandstone filling of the channel is interpreted as the lowstand systems tract. Tinedhan, upper Marar Formation. (B) A $10 \mathrm{~m}$ thick fluvial channel crops out as a lenticular sandbody. Al Awaynat, upper Marar Formation. (C) Detail image of the sedimentary fill of the channel, shown in (B). About $1 \mathrm{~m}$ thick planar and trough cross-stratified sets occur, bounded by erosion surfaces. (D) Detail image of the channel base, showing the erosional unconformity between the sandstones above and the offshore shales below. (E) Outcrop photograph of laterally very persistent, gradually thickening and coarsening upward cycles of the upper Marar Formation near Awaynat Wanin. Dashed line indicates the Hercynian unconformity between the Marar Formation and the Cretaceous Mizdah Formation. (F) Detail image of (E). A vertical facies change occurs from offshore shales to hummocky cross-stratified sandstones, wave-ripple-laminated sandstones and multidirectional cross-stratified sandstones, interpreted as a marine shallowing upward cycle. The rose diagram shows palaeocurrent directions measured from trough cross-bedding. 
the top. The maximum regression at the top of the sequence in both areas led to the incision of fluvial channels in marine shales.

\subsection{Lower Carboniferous sequence 2 (LC 2)}

While a palaeosol was established in Awaynat Wanin at the base of LC 2, the incised channels in Tinedhan and Al Awaynat were filled with fluvial sands. The following transgression led to the cyclic deposition of hummocky cross-stratified (HCS) sandstones and shales in Tinedhan; the shales are slightly thickening upward. In the Al Awaynat area, the maximum transgression within LC 2 is placed in a relatively thick shale succession, above a limestone bed (Fig. 6). The latter indicates minimum clastic input during LC 2. Regressive deposits above are represented by shallow marine clastics and shales, whereby the shales thin upward.

\subsection{Lower Carboniferous sequence 3 (LC 3)}

The base of sequence LC 3 is most obvious in Tinedhan, where a $27 \mathrm{~m}$ thick fluvial sandstone within an incised valley shows that a considerable regression occurred. In the south (Al Awaynat), a conglomerate is interpreted to represent this stratigraphic level. Towards the north (Awaynat Wanin), however, no indications of subaerial exposure occur but shallow marine to tidal clastics dominate. It is therefore interpreted that the coastline during this regression was situated between Awaynat Wanin and Tinedhan.

Transgressive deposits of LC 3 are dominated by offshore shales with some intercalations of HCS sandstones in Tinedhan. After the turnaround to regressive deposition, which is situated within a thick shale succession, shallow marine clastics occur with increasing frequency.

\subsection{Lower Carboniferous sequence 4 (LC 4)}

The base of this sequence is very pronounced in Al Awaynat and Tinedhan, where ca. $10 \mathrm{~m}$ and ca. $50 \mathrm{~m}$ thick fluvial sandstones occur within incised valleys (Fig. 6). A palaeosol developed in Awaynat Wanin during this regression. The following transgression led to the deposition of shallow marine clastics and carbonates. The stromatolitic marker beds (Collenia, see Section 2.2.) occur within LC 4; they are succeeded by offshore shales. Subsequent regression again led to the deposition of shallow marine clastics and carbonates.

\subsection{Lower Carboniferous sequence 5 (LC 5)}

In Awaynat Wanin and Tinedhan, the base of this sequence is represented by fluvial channels, cutting into marine shales (Fig. 7). This maximum regression most-likely correlates with a conglomerate in Al Awaynat. During the following transgression, marine carbonates were more and more deposited throughout the investigated area and shallow marine clastics became rare. The middle of a relatively thick offshore shale succession is interpreted as the turnaround from transgression to regression; shallow marine carbonates are dominating the upper, regressive part of LC 5.

\section{Discussion}

\subsection{Sequence stratigraphy}

According to Carr (2002), the base and the top of Carboniferous deposits represent second-order sequence boundaries throughout North Africa. These two sequence boundaries are very prominent in parts of western Libya. A minor unconformity between upper Famennian and upper Tournaisian rocks can be recognised west of Awaynat Wanin (Massa et al., 1980), and a major unconformity between the Silurian Tanezzuft Formation and upper Tournaisian rocks occurs between Tinedhan and Al Awaynat (Protic, 1984). The unconformity at the top of Carboniferous strata is related to the Hercynian Orogeny.

This study provides good sedimentological evidence for a number of higher order sequence boundaries within Carboniferous strata in western Libya. The Marar and Assedjefar Formations (late Tournaisian to late Serpukhovian) are subdivided into five sequences, which are separated by unconformities interpreted to be created by relative sea-level falls. This led to subaerial exposure and a repeated establishment of a fluvial channel system on the exposed shelf.

In Tinedhan, fluvial channel sandstones erosively cut down $15 \mathrm{~m}$ and $50 \mathrm{~m}$ into offshore marine or storm deposits (Fig. 6). The bases of the fluvial channels are interpreted as third-order sequence boundaries; the fluvial sandstone fill records deposition during the lowstand systems tract. Palaeosols were not found on the interfluves in Tinedhan, which indicates that transgression at the base of the transgressive systems tract (TST) probably had enough energy to erode any palaeosols that were developed and possibly the upper part of the fluvial sandstones. According to Posamentier and Allen (1999), a transgressing shoreline can erode up to $20 \mathrm{~m}$ of sediment in areas of high wave energy. In the interfluves at Tinedhan, offshore shales containing storm deposits interpreted to be part of the basal TST overlie the same sedimentary facies from the upper highstand systems tract (HST). So in the interfluve areas, the sequence boundary and the transgressive surface are identical. It can be recognised by a thin pebble lag.

Facies development within the HSTs and TSTs is very similar. However, the stacking pattern of the cycles typically shows thinning upward sandstone beds in the TST and thickening upward in the HST. Distinct maximum flooding surfaces could not be determined in the field; instead, the middle of the thickest shale succession, located at the top of the thinning upward trend of the sandstone beds, is interpreted as a maximum flooding zone.

Following SB 1 at the base of the Carboniferous, three sequence boundaries occur within the Marar Formation (SB 2-SB 4) (Fig. 6). Biostratigraphic data (e.g. Massa et al., 1980; Coquel and Massa, 1993; Mergl and Massa, 2000) suggest that they all occur within the Viséan. One sequence boundary (SB 5) was identified within the Serpukhovian lower Assedjefar Formation (Fig. 7). There was no sedimentological evidence of subaerial exposure or significant erosion within the Dembaba Formation, and as such no sequence boundaries could be recognised.

The expression of SB 2 and SB 4 in Al Awaynat is similar to that in Tinedhan, however, the fluvial channel sandstones are thinner. SB 3 and SB 5 correlate with conglomeratic layers interpreted as transgressive lags.

In Awaynat Wanin, SB 2 and SB 4 are defined by palaeosols consisting of red, mottled siltstones with rootlets (Facies 27). In between these two sequence boundaries, no evidence for subaerial exposure was observed, and as such a correlative conformity to SB 3 is interpreted at this locality.

\subsection{Palaeogeographic implications}

Western Libya was located in a dominantly marine setting on a stable platform during the Early Carboniferous, with a transition to an exposed continental landmass towards the south (Guiraud et al., 2005). Slope and deep-water deposition took place in the area from northern Tunisia to central Morocco. Results from this study confirm that the majority of sediments from late Tournaisian to Moscovian times were deposited in a shallow marine environment. However, the identification of sequence boundaries with evidence for significant erosion, fluvial deposition and/or palaeosols indi- 
cates that during at least four periods within the Early Carboniferous, western Libya was partly or completely subaerially exposed due to relative sea-level fall and regression. Fig. 9 shows the inferred palaeogeographic setting during each of these four sea-level lowstands.

Large (15-50 m thick) fluvial channel systems identified in the Marar Formation of Tinedhan, have palaeocurrents indicating flow towards the northwest. Smaller (2-10 m thick) fluvial channels/ channel systems show a variety of palaeocurrent directions, suggesting they feed into the main fluvial system. This correlates with findings from other authors who investigated Palaeozoic flow directions in this area (e.g. Selley, 1997; Vos, 1981). If the Murzuq Basin was a syndepositional basin during the Carboniferous, as suggested by a palaeogeographic reconstruction of Carr (2002), it would be expected that fluvial channels would have a dominant palaeoflow direction from the basin margins towards the centre to the south-east. This clearly is not the case.

A lateral facies trend towards deeper marine deposits in the basin centre also was not observed: the dominant deposits in all investigated outcrop areas are shallow marine sandstones and carbonates (shoreface to storm wave base) alternating with offshore shales, which thicken to the north and west. A similar depositional environment was described from subsurface studies of the Murzuq Basin (Aziz, 2000; Hallett, 2002). Additionally, there is no trend towards thicker Carboniferous strata in the centre of the Murzuq Basin relative to the margins (Boote et al., 1998; Davidson et al., 2000). Luning et al. (1999, p. 714) proposed that from Ordovician to mid-Carboniferous times a more or less interconnected North African depositional shelf system existed, which is supported by the palaeogeographic maps of Guiraud et al. (2005). Local tectonic uplifts, e.g. the Tihemboka Arch and the Gargaf Arch, were proba- bly not related to basin forming processes, as they also occur within the centre of the Murzuq Basin (Adamson, 1999). Consequently, the Murzuq Basin is interpreted as a postdepositional basin relative to the Carboniferous.

The prominent increase in thickness of the Marar Formation from south to north, which was already noted by Grubic et al. (1991), is interpreted as the result of a gradual increase in subsidence and accommodation space towards the north. A trend towards a slightly deeper depositional environment towards the north was observed in the lowstand systems tract 3 (Fig. 9): a fluvial system in Tinedhan was probably established adjacent to a marine depositional environment in Awaynat Wanin.

\subsection{Controls on relative sea-level changes}

The three sea-level lowstands identified in the Marar Formation are dated as most-likely Visean in age, and the lowstand of the lower Assedjefar Formation is of early Serpukhovian age. The lack of unconformities and major changes in the depositional environment suggests that the sea-level remained relatively stable from the middle Assedjefar Formation to the top Dembaba Formation, except for a probable transgression at the base of the Dembaba Formation, which is most likely of early Bashkirian age (Fig. 7).

The eustatic sea-level curve for the Carboniferous period from Ross and Ross (1988) shows three long-lived regressions during the Viséan (Fig. 10) and one regressive peak at the very base of the Serpukhovian. These four eustatic regressions may correlate with the four observed regressions in western Libya, however, due to the lack of detailed biostratigraphic data from Libya at this time this cannot be confirmed. A prominent eustatic regressive peak in the middle Serpukhovian and a major regression in the
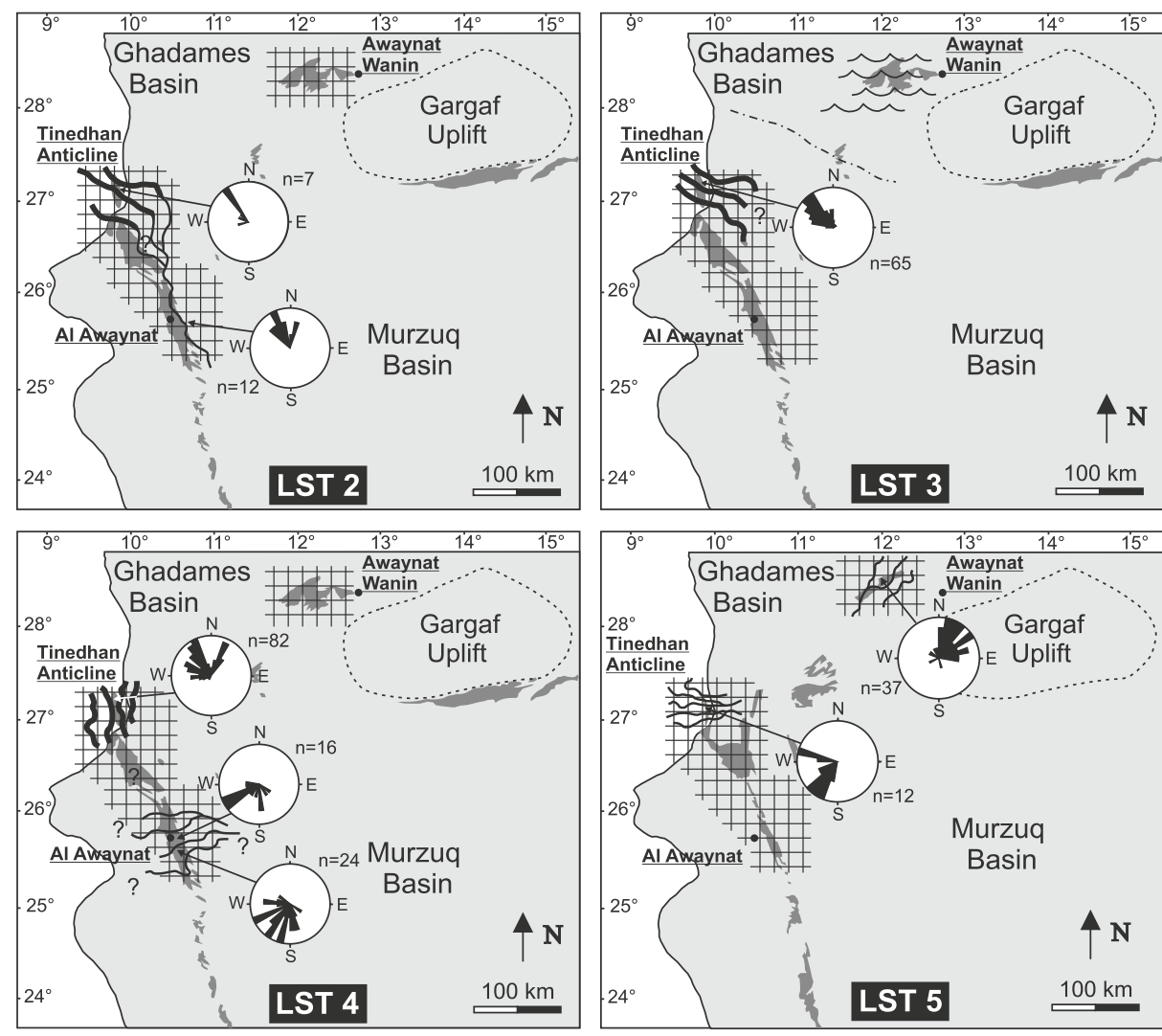

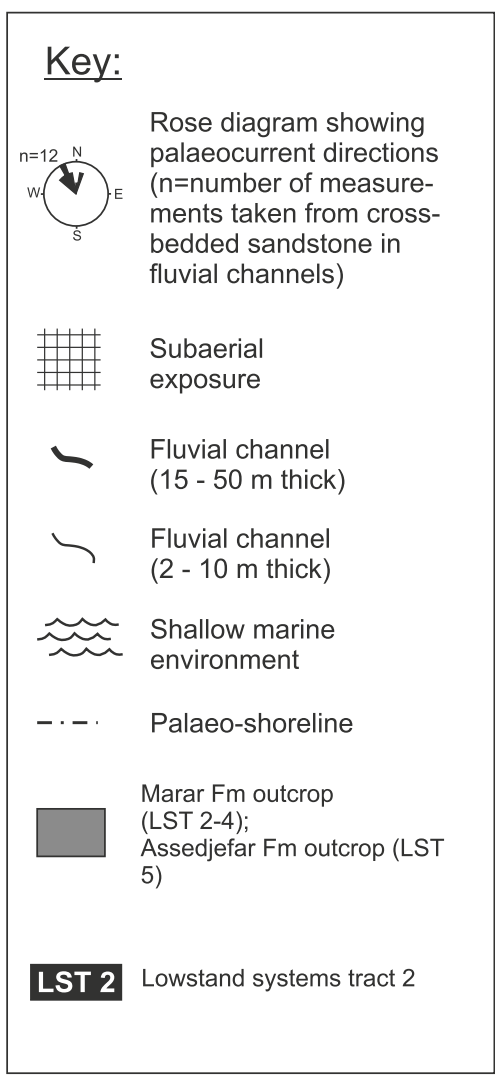

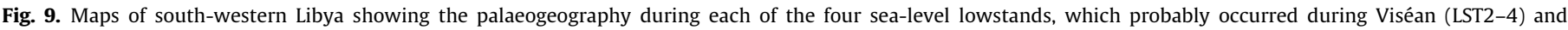
Serpukhovian (LST5) times. 


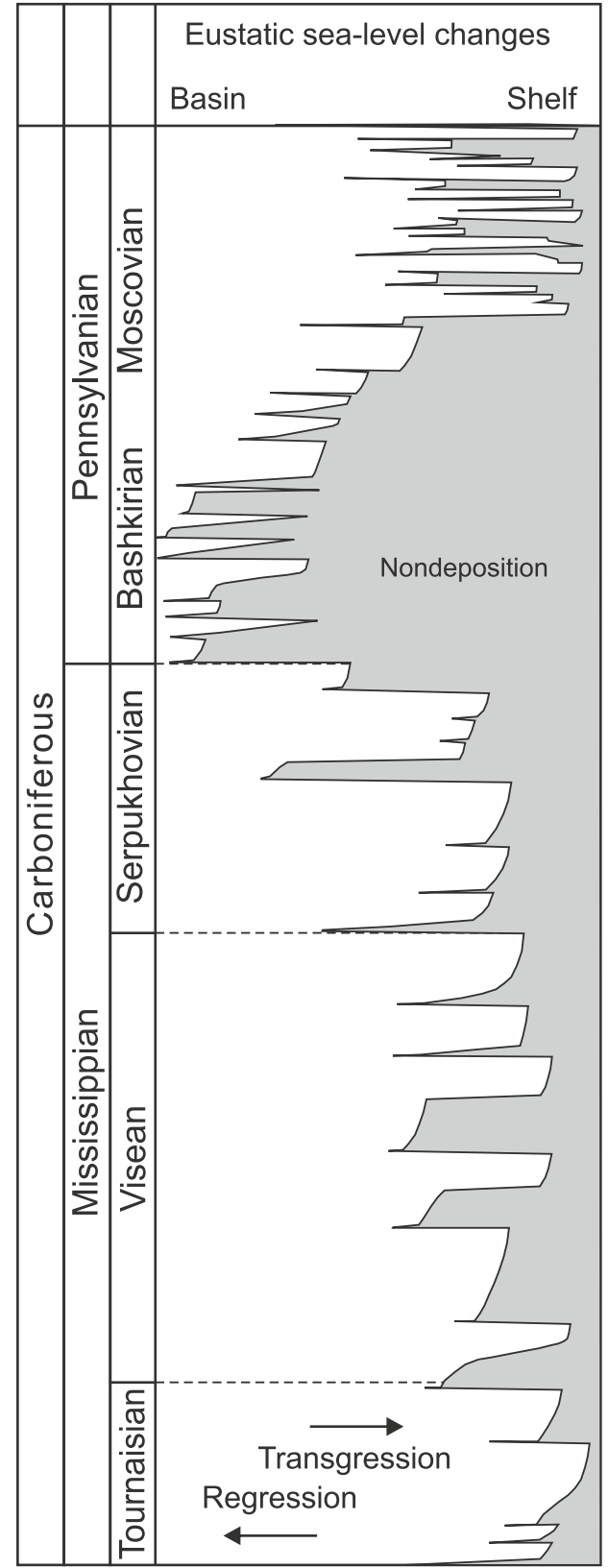

Ross \& Ross (1988)

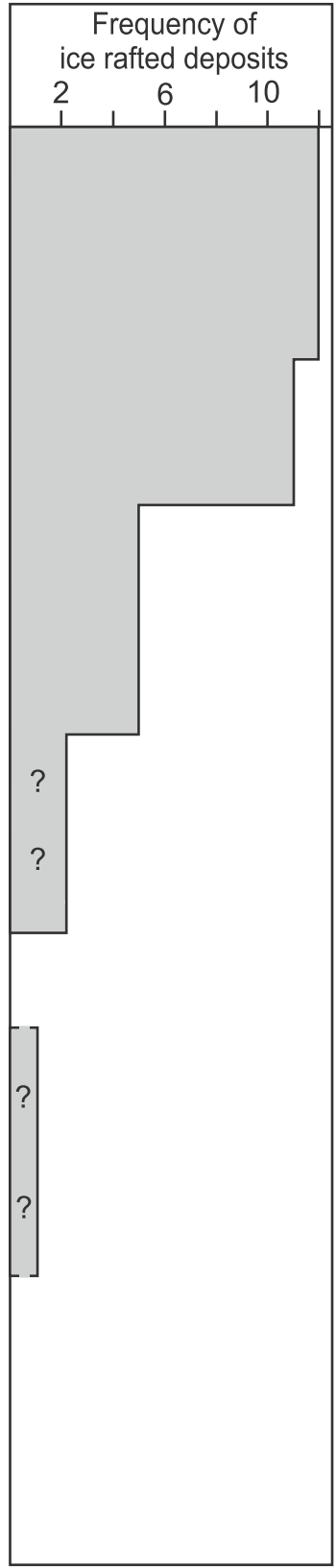

Frakes et al. (1992), Smith \& Read (2000)
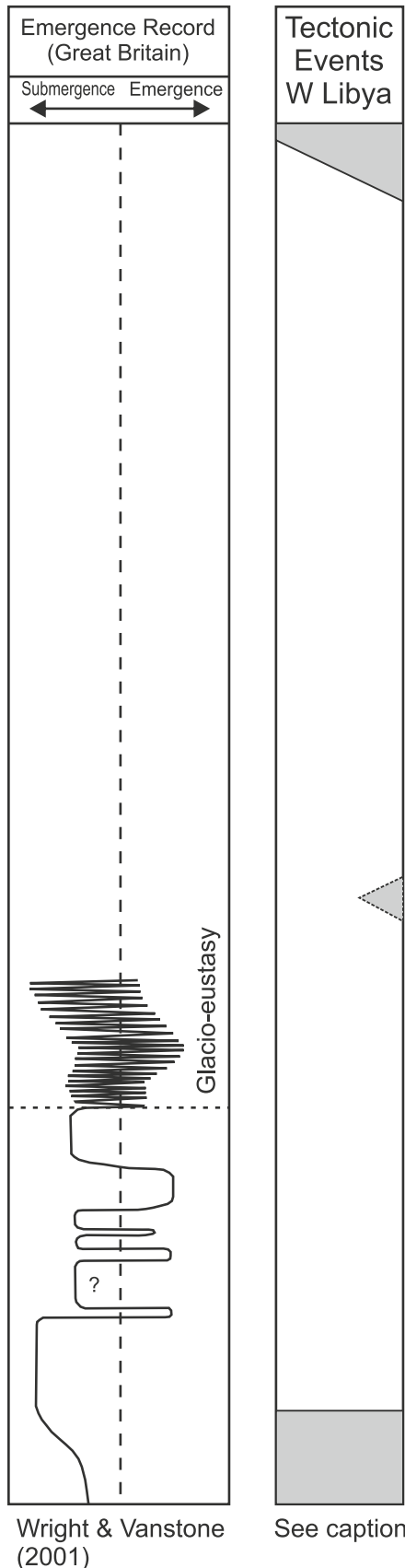

See caption

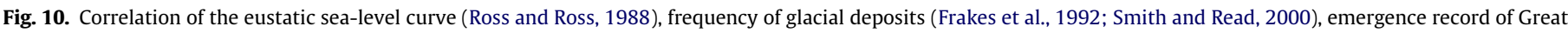

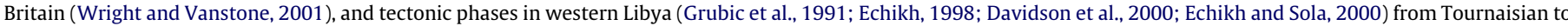

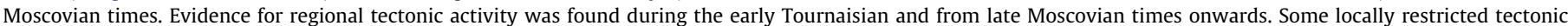
activity occurred between Viséan and Serpukhovian times.

Bashkirian, the mid-Carboniferous eustatic event (Saunders and Ramsbottom, 1986), cannot be recognised in the strata of western Libya.

The Late Palaeozoic Ice Age had a major impact on sea-level change during the Carboniferous. According to Fielding et al. (2008), short precursor glaciations occurred at the Famennian/ Tournaisian boundary and in the Viséan. The onset of peak glaciation occured during the early Serpukhovian, becoming more widespread by the Bashkirian, when continental glacial deposits developed for example in Congo, Eritrea and southern Arabia (Schandelmeier and Reynolds, 1997). Wright and Vanstone (2001) studied carbonate successions in the UK and identified glacio-eustatic signals in the middle Viséan, i.e. before the maximum expansion of glaciers (Fig. 10). Although precise dating is limited, LST 3 to LST 5 of western Libya probably record the glacio-eustatic control, from the middle Viséan to the early Serpukhovian (Fig. 6 and 7). However, glacio-eustatic influence is unlikely for the earlier LST 2 of early Viséan age.

Tectonic activity in western Libya has been recorded during the early, middle and late Carboniferous. An increasing hiatus from south to north in the area of the Tihemboka Arch between basal Carboniferous units and underlying strata indicates pre-Carboniferous uplift and erosion of parts of the western Murzuq Basin margin (Grubic et al., 1991; Hallett, 2002).

In some areas of the central Murzuq Basin, seismic data show transpressional faults and local erosional unconformities between 
the Marar and Assedjefar Formations which are related to mid-Carboniferous compression (Davidson et al., 2000; Echikh and Sola, 2000). However, mid-Carboniferous tectonic movements seem to be restricted to a few local areas and not regional in extent. Significant tectonic unconformities or evidence of structural movements were not observed in outcrops examined in this study.

The main Hercynian tectonic phase started during the Late Carboniferous and Early Permian and strongly affected sedimentary basins throughout North Africa (Boote et al., 1998). In western Libya the early precursor to this tectonism and regional inversion resulted in the transition from marine deposition in the Dembaba Formation to continental deposition in the Tiguentourine Formation with eventual large-scale emergence and non-deposition during the Permian. The Illizi and Ghadames Basins were more significantly affected by regional tilting than the Murzuq Basin (Echikh, 1998; Davidson et al., 2000). During the deposition of the Marar, Assedjefar and Dembaba Formations there was little recorded tectonic activity except for a brief and locally restricted phase between the Marar and Assedjefar Formations. Tectonic movements are thus not considered to be the main control on repeated large-scale emergence of western Libya during the Early Carboniferous. The relative sea-level fall and associated emergence of highstand deposits and subsequent incision of a fluvial system were most-likely controlled by eustatic changes in sea-level.

\subsection{Controls on the transition from a siliciclastic to a carbonate depositional environment}

The Marar Formation in western Libya consists of siliciclastic deposits with very few intercalated carbonate layers. Within the Assedjefar Formation, the ratio of carbonate to siliciclastic increases steadily until there is almost only carbonate deposition in the Dembaba Formation. Sedimentary structures and stacking patterns would suggest that the dominant water depth and depositional environment, however, remains very similar: siliciclastic storm and shoreline deposits are replaced by carbonate storm and shoreline deposits.

The major climate change during the Carboniferous period expressed by the onset of the Late Palaeozoic Ice Age is well documented (e.g. Veevers and Powell, 1987; Fielding et al., 2008). Temperatures in Africa were probably cooling during the early Bashkirian, as indicated by the development of continental glacial deposits in Congo, Eritrea and southern Arabia (Schandelmeier and Reynolds, 1997). The Carboniferous fauna in western Libya are a typical heterozoan assemblage and thus could have lived in warm or cold waters. Hence temperature change alone is an unlikely reason for the onset of carbonate production.

The source of the siliciclastic sediments, i.e. the exposed land to the south, probably remained in about the same position relative to the area of deposition in western Libya from Tournaisian to Moscovian times (Guiraud et al., 2005).

This suggests that it is unlikely that changes in water depth, distance to source area and temperature changes were the main controls on a change from a dominantly siliciclastic to a carbonate depositional system.

A possible control could be the reduction of clastic sediment transport from the hinterland to the shelf from the Viséan to the Bashkirian, either linked to a local increase in aridity and/or to the gradual erosion and decreasing topography of the hinterland mountains. An example for this mechanism can be found in Cenozoic deposits of the southern Australian shelf (James and von der Borch, 1991). Of special interest are the studies of Raymond et al. (1985) and Wright (1990) who propose seasonal high humidity in northern Gondwana during the Early Carboniferous due to a major low pressure zone which drew in equatorial air. This theory is supported by the occurrence of arborescent lycopsids in the Marar and Assedjefar Formations which indicates that a wet or humid climate prevailed in western Libya during the Early Carboniferous (Meyer-Berthaud, pers. comm.) It is hypothesised that the considerable climate changes due to the collision of Gondwana and Laurussia and the onset of Late Carboniferous icehouse conditions led to increased aridity over northern Gondwana and thus the transition from siliciclastic to carbonate dominated sedimentation due to a strongly reduced clastic discharge into the basin.

\section{Conclusions}

This study uses outcrop information from the central Sahara to document the changes in the sedimentary system of northern Gondwana during the Carboniferous.

The main conclusions are:

1. Lower Carboniferous deposits of western Libya consist of five depositional sequences, which are divided by 3rd order sequence boundaries.

2. The lowstand systems tracts are expressed as $1.5 \mathrm{~m}$ thick (ca. $40 \mathrm{~m}$ wide) to $50 \mathrm{~m}$ thick (ca. $1.5 \mathrm{~km}$ wide) incised channel systems filled entirely with fluvial sandstones. The dominant palaeoflow direction of large channels (thicker than $15 \mathrm{~m}$ ) is towards northwest; smaller channels show a variety of palaeoflow directions, suggesting they feed into the main fluvial system.

3. Sea-level lowstand led to the exposure of most of the western Libyan shelf three times during the Viséan and once during the early Serpukhovian.

4. Both the transgressive (TST) and highstand (HST) systems tracts of the Lower Carboniferous are dominantly made up of shallow marine, siliciclastic storm and shoreline deposits alternating with offshore shales. TSTs typically show a thinning upward of the sandstone units, while HSTs show a thickening upward of sandstone units.

5. Deposition of carbonate sediments gradually increased during the Serpukhovian. Bashkirian and Moscovian strata are dominated by shallow marine, calcareous storm and shoreline deposits. These are predominantly made up of fragments of a heterozoan fauna in addition to ooids, peloids, extraclasts and quartz grains. Carbonate buildups are absent.

6. There is no evidence for significant tectonic activity in the region, suggesting that in western Libya, relative sea-level changes during the Carboniferous were dominantly controlled by eustasy.

7. The Murzuq Basin was most-likely interconnected with the Ghadames Basin during the Carboniferous. With regard to the Carboniferous interval, it is a postdepositional basin. The palaeogeographic trend is towards a gradually deepening depositional environment towards the north during the late Tournaisian and Viséan.

8. The gradual transition from a clastic dominated depositional environment during the late Tournaisian and Viséan to a carbonate depositional environment during the Bashkirian and Moscovian is interpreted to record the local increase in aridity and/or decreasing topography of the clastic source area in the hinterland.

\section{Acknowledgements}

We are grateful to the sponsors of the North Africa Research Group for financial support. Woodside Energy N.A. provided additional financial and logistical support in the field. The help of J. Guest, K. Morisson and T. Rehill (all Woodside Energy) is especially 
acknowledged. We like to thank B. Meyer-Berthaud (Montpellier) for identifying plant samples, and D. Korn (Berlin) for identifying cephalopods. The suggestions of the reviewers D. Hallett and S. Lüning improved the paper, which is gratefully acknowledged.

\section{References}

Abugares, Y.I., 2003. The Petroleum geology of the Palaeozoic clastics of the Murzuq Basin, Al'Atshan saddle and the southern part of the Ghadames Basin, Libya. In: Salem, M.J., Oun, K.M. (Eds.), The Geology of Northwest Libya. Earth Science Society of Libya, Tripoli, pp. 213-244.

Adamson, K., 1999. Evolution of the Murzuq Basin, southwest Libya, and surrounding region during the Devonian. Ph.D. Thesis, Univ. of Wales, Aberystwyth.

Aziz, A., 2000. Stratigraphy and hydrocarbon potential of the lower Palaeozoic succession of licence NC 115, Murzuq Basin, SW Libya. In: Sola, M.A., Worsley, D. (Eds.), Symposium on Geological Exploration in Murzuq Basin. Elsevier, Amsterdam, pp. 349-368.

Belhaj, F., 2000. Carboniferous and devonian stratigraphy - the M'rar and Tadrart reservoirs, Ghadames Basin, Libya. In: Sola, M.A., Worsley, D. (Eds.), Geological Exploration in Murzuq Basin. Elsevier Science B.V., pp. 117-142.

Bellini, E., Massa, D., 1980. A Stratigraphic contribution to the Palaeozoic of the southern Basins of Libya. In: Salem, M.J., Busrewil, M.T. (Eds.), The Geology of Libya. Academic Press, London, pp. 3-56.

Berendeyev, N.S., 1985. Sheet Hamadat Tanghirt (NH 32-16), Geological Map of Libya, Scale 1:2,50,000, Explanatory Booklet. Industrial Research Centre, Tripoli.

Boote, D.R.D., Clark-Lowes, D.D., Traut, M.W., 1998. Palaeozoic petroleum systems of North Africa. In: MacGregor, D.S., Moody, R.T.J., Clark-Lowes, D.D. (Eds.), Petroleum Geology of North Africa. Geological Society, London, pp. 7-68. Special publication.

Carr, I.D., 2002. Second-order sequence stratigraphy of the Palaeozoic of North Africa. J. Petrol. Geol. 25 (3), 259-280.

Coquel, R., Massa, D., 1993. Apropos d'evenements palynologiques du Carbonifere inferieur (=Mississippien) d'Afrique du Nord. Ann. Soc. Geol. Nord 2, 145-152.

Davidson, L., Beswetherick, S., Craig, J., Eales, M., Fisher, A., Himmali, A., Jho, J., Mejrab, B., Smart, J., 2000. The structure, stratigraphy and petroleum geology of the Murzuq Basin, southwest Libya. In: Sola, M.A., Worsley, D. (Eds.), Geological Exploration in Murzuq Basin. Elsevier Science B.V., pp. 295-320.

Dumas, S., Arnott, R.W.C., 2006. Origin of hummocky and swaley cross-stratification - the controlling influence of unidirectional current strength and aggradation rate. Geology 34 (12), 1073-1076.

Echikh, K., 1998. Geology and hydrocarbon occurrences in the Ghadames Basin, Algeria, Tunisia, Libya. In: MacGregor, D.S., Moody, R.T.J., Clark-Lowes, D.D. (Eds.), Petroleum Geology of North Africa. Geological Society, London, pp. 109129. Special publication.

Echikh, K., Sola, M.A., 2000. Geology and hydrocarbon occurrences in the Murzuq Basin, SW Libya. In: Sola, M.A., Worsley, D. (Eds.), Geological Exploration in Murzuq Basin. Elsevier Science B.V., pp. 175-222.

Fabre, J., 1970. Le Paleozoique terminal a facies gres rouge au Sahara central et occidental. C.R. 6eme Congr. Int. Stratigr. Geol. Carbonifere (Sheffield, 1967) 2, 737-744.

Fielding, C., Frank, T.D., Isbell, J.L., 2008. Timing, Duration and Character of Glaciation During the Late Paleozoic Ice Age. AAPG Annual Convention and Exhibition, Abstracts Volume, San Antonio, p. 59.

Flügel, E., 2004. Microfacies of Carbonate Rocks. Springer, Berlin. p. 976.

Frakes, L.A., Francis, J.E., Syktu, J.I., 1992. Climate Modes of the Phanerozoic. University Press, Cambridge. 274 pp.

Freulon, J.M., 1953. Existance d'un niveau a stromatolites (Collenia) dans le Carbonifere marin du Sahara Oriental. Societe Geologique de France, C.R. Somm. Seanc. 11-12, 233-234.

Galecic, M., 1984. Sheet Anay (NG 32-16), Geological Map of Libya, Scale 1:2,50,000, Explanatory Booklet. Industrial Research Center, Tripoli.

Grubic, A., Dimitrijevic, M., Galecic, M., Jakovljevic, Z., Momarnicki, S., Protic, D., Radulovic, P., Roncevic, G., 1991. Stratigraphy of western Fezzan (SW Libya). In: Salem, M.J., Belaid, M.N. (Eds.), The Geology of Libya. Academic Press, London, pp. 1529-1564.

Guiraud, R., Bosworth, W., Thierry, J., Delplanque, A., 2005. Phanerozoic geological evolution of northern and central Africa: an overview. J. African Earth Sci. 43 (13), 83-143.

Gundobin, V.M., 1985. Sheet Qararat al Marar (NH 33-13), Geological Map of Libya, Scale 1:2,50,000, Explanatory Booklet. Industrial Research Center, Tripoli.

Hallett, D., 2002. Petroleum Geology of Libya. Elsevier B.V., Amsterdam. p. 503.

Jakovljevic, Z., 1984. Sheet Al Awaynat (NG 32-12), Geological Map of Libya, scale $1: 2,50,000$, Explanatory Booklet. Industrial Research Center, Tripoli.

James, N.P., von der Borch, C.C., 1991. Carbonate shelf edge off southern Australia: a prograding open-platform margin. Geology 19, 1005-1008.

Klitzsch, E., 1963. Geology of the north-east flank of the Murzuk basin (Djebel Ben Ghenema - Dor El Gussa area). Rev. Inst. Fr. Petrole 18, 1411-1427.

Klitzsch, E., 1970. Die Strukturgeschichte der Zentralsahara. Neue Erkenntnisse zum Bau und zur Palaeogeographie eines Tafellandes. Geol. Rundschau 59, 459-527.

Krumbeck, L., 1906. Beiträge zur Geologie und Paleontologie von Tripolis. Palaeontographica 53.
Lapparent, A.F., Lelubre, M., 1948. Interpretation stratigraphique des series continentales entre Ohanet et Bourharet (Sahara central). C.R. Acad. Sci. Paris 227, 1106-1108.

Leinfelder, R.R., Schmid, D.U., 2000. Mesozoic reefal thrombolites and other microbialites. In: Riding, R.E., Awramik, S.M. (Eds.), Microbial Sediments. Springer, New York, pp. 289-294.

Lelubre, M., 1948. La Paleozoique du Fezzan sudoriental. Compte Rendus Soc. Geol. France 18, 79-81.

Lelubre, M., 1952. Apercu sur la geologie du Fezzan. Bull. Serv. de la carte Geol. d'Algeri. Traveaux Recent. Collaborateurs 3, 109-148.

Luning, S., Craig, J., Fitches, B., Mayouf, J., Busrewil, A., El Dieb, M., Gammudi, A., Loydell, D.K., McIlroy, D., 1999. Re-evaluation of the petroleum potential of the Kufra Basin (SE Libya, NE Chad): does the source rock barrier fall? Marine Petrol. Geol. 16, 693-718.

Makhlouf, I.M., 2000. Early Triassic intertidal/subtidal patterns of sedimentation along the southern margins of the Tethyan seaway, Jordan. J. Asian Earth Sci. 18 (5), 513-518

Massa, D., Termier, G., Termier, H., 1974. Le Carbonifere de Libye occidentale: stratigraphie et paleontologie. Notes et Mem. - Comp. Franc. Petroles 11, 139206.

Massa, D., Coquel, R., Loboziak, S., Taugourdeau-Lantz, J., 1980. Essai de synthese stratigraphique et palynologique du Carbonifere en Libye occidentale. Ann. Soc Geol. Nord 99, 429-442.

McKerrow, W.S., Mac Niocaill, C., Ahlberg, P.E., Clayton, G., Cleal, C.J., Eagar, M.C. 2000. The Late Palaeozoic relations between Gondwana and Laurussia. In: Franke, W., Haak, V., Oncken, O., Tanner, D. (Eds.), Orogenic Processes: Quantification and Modelling in the Variscan Belt. Geological Society, London, pp. 9-20. Special publications.

Menning, M., Alekseev, A.S., Chuvashov, B.I., Davydov, V.I., Devuyst, F.X., Forke, H.C., Grunt, T.A., Hance, L., Heckel, P.H., Izokh, N.G., Jin, Y.G., Jones, P.J., Kotlyar, G.V., Kozur, H.W., Nemyrovska, T.I., Schneider, J.W., Wang, X.D., Weddige, K., Weyer D., Work, D.M., 2006. Global time scale and regional stratigraphic reference scales of Central and West Europe, East Europe, Tethys, South China, and North America as used in the Devonian-Carboniferous-Permian correlation chart 2003 (DCP 2003). Palaeogeogr., Palaeoclimatol., Palaeoecol. 240 (1-2), 318-372.

Mergl, M., Massa, D., 2000. A Palaeontological review of the Devonian and Carboniferous succession of the Murzuq Basin and the Djado Sub-Basin. In: Sola, M.A., Worsley, D. (Eds.), Geological Exploration in Murzuq Basin. Elsevier Science B.V., pp. 41-88.

Owen, G., 1996. Experimental soft-sediment deformation: structures formed by the liquefaction of unconsolidated sands and some ancient examples. Sedimentology 43 (2), 279-293.

Posamentier, H.W., Allen, G.P., 1999. Siliciclastic Sequence Stratigraphy - Concepts and Applications. Concepts in Sedimentology and Paleontology, vol. 7. SEPM, Tulsa, p. 204.

Protic, D., 1984. Sheet Tikiumit (NG 32-7), Geological Map of Libya, Scale 1:2,50,000, Explanatory Booklet. Industrial Research Center, Tripoli.

Raymond, A., Parker, W.C., Totman Parrish, J., 1985. Phytogeography and palaeoclimate of the Early Carboniferous. In: Tiffney, B.H. (Ed.), Geological Factors and the Evolution of Plants. Yale University Press, New Haven, pp. 169222.

Reineck, H.-E., Singh, I.B., 1980. Depositional sedimentary environments. Springer Verlag, Berlin. p. 549

Ross, C.A., Ross, J.R.P., 1988. Late Paleozoic transgressive-regressive deposition. In: Wilgus, C.W. (Ed.), Sea-Level Changes - An Integrated Approach. SEPM, pp. 227 247, Special publications 42.

Saunders, W.B., Ramsbottom, W.H.C., 1986. The mid-Carboniferous eustatic event. Geology 14, 208-212.

Schandelmeier, H., Reynolds, P.O., 1997. Palaeogeographic-Palaeotectonic Atlas of North-Eastern Africa, Arabia and Adjacent Areas. Balkema, Rotterdam. p. 160.

Scotese, C.R., 2000. PALEOMAP Project. <www.scotese.com>

Selley, R.C., 1997. The sedimentary basins of Northwest Africa: Stratigraphy and sedimentation. In: Selley, R.C. (Ed.), African Basins, vol. 3. Elsevier, Amsterdam, pp. 3-16. Sedimentary Basins of the World.

Smith, L.B., Read, J.F., 2000. Rapid onset of late Paleozoic glaciation on Gondwana: evidence from Upper Mississippian strata of the Midcontinent, United States. Geology 28 (3), 279-282.

Tait, J., Schaetz, M., Bachtadse, V., Soffel, $\mathrm{H}, 2000$. Palaeomagnetism and Palaeozoic palaeogeography of Gondwana and European terranes. In: Franke, W., Haak, V. Oncken, O., Tanner, D. (Eds.), Orogenic Processes: Quantification and Modelling in the Variscan Belt. Geological Society, London, pp. 21-34. Special publications.

Vachard, D., Massa, D., 1984. The Carboniferous of western Libya. In: Sutherland, P.K., Manger, W.L. (Eds.), Biostratigraphy. International Congress on Carboniferous Stratigraphy and Geology, pp. 165-174.

Veevers, J.J., Powell, C., 1987. Late Paleozoic glacial episodes in Gondwanaland reflected in transgressive-regressive depositional sequences in Euramerica. Geol. Soc. Am. Bull. 98, 475-487.

Vos, R.G., 1981. Deltaic sedimentation in the Devonian of western Libya. Sediment. Geol. 29, 67-88.

Whitbread, T., Kelling, G., 1982. Mrar Formation of western Libya - evolution of an early Carboniferous delta system. AAPG Bull. 66 (8), 1091-1107.

Wright, V.P., 1990. Equatorial aridity and climatic oscillations during the Early Carboniferous, southern Britain. J. Geol. Soc., London 147, 359-363.

Wright, V.P., Vanstone, S.D., 2001. Onset of Late Palaeozoic glacio-eustasy and the evolving climates of low latitude areas: a synthesis of current understanding. J. Geol. Soc. London 158 (4), 579-582. 